\title{
Can agroecology and CRISPR mix? The politics of complementarity and moving toward technology sovereignty
}

\author{
Maywa Montenegro de Wit $^{1}$ (D)
}

Accepted: 3 November 2021 / Published online: 5 December 2021

(c) The Author(s) 2021

\begin{abstract}
Can gene editing and agroecology be complementary? Various formulations of this question now animate debates over the future of food systems, including in the UN Committee on World Food Security and at the UN Food Systems Summit. Previous analyses have discussed the risks of gene editing for agroecosystems, smallholders, and the concentration of wealth by and for agro-industry. This paper takes a different approach, unpacking the epistemic, socioeconomic, and ontological politics inherent in complementarity. I ask: How is complementarity understood? Who is asking and defining this question? What are the politics of entertaining the debate at all? I sketch the epistemic foundations of science and technology that organize different notions of evidence used in agroecology and genetic engineering. On this base, I offer 8 angles on the compatibility question, exploring the historical contradictions that complementarity discourses reveal and the contemporary work they do. I work through questions of (1) technological neutrality, (2) "root cause" problems, (3) working with nature, (4) encoding racism, and dilemmas of (5) ownership and (6) access. These questions, I argue, require a reckoning with (7) ontologies of coloniality-modernity, which help us get underneath—and beyond—-the complementarity question. Finally, I offer (8) a framework for thinking about and working toward technology sovereignty.
\end{abstract}

Keywords Agroecology $\cdot$ Gene editing $\cdot$ Biotechnology $\cdot$ Colonialism $\cdot$ Food sovereignty $\cdot$ Technology sovereignty

$\begin{array}{ll}\text { Abbreviations } \\ \text { AI } & \text { Artificial intelligence } \\ \text { BIPOC } & \text { Black, indigenous, and people of color } \\ \text { CRISPR } & \begin{array}{l}\text { Clustered regularly interspaced short palin- } \\ \text { dromic repeats }\end{array} \\ \text { CRISPR/Cas } & \text { CRISPR/CRISPR associated systems } \\ \text { DIY } & \text { Do-It-Yourself } \\ \text { DNA } & \text { Deoxyribonucleic acid } \\ \text { FAO } & \text { Food and Agriculture Organization } \\ \text { GMO } & \text { Genetically modified organism } \\ \text { HLPE } & \text { High level panel of experts } \\ \text { IP } & \text { Intellectual property } \\ \text { SI } & \text { Sustainable Intensification } \\ \text { STS } & \text { Science and Technology Studies } \\ \text { UNFSS } & \text { UN Food Systems Summit }\end{array}$

Maywa Montenegro de Wit

mamonten@ucsc.edu

1 Department of Environmental Studies, University of California, Santa Cruz, 1156 High Street, Santa Cruz, CA 95064, USA

\section{Introduction}

Is gene editing compatible with agroecology? Anticipating this question, in 2008, plant geneticist Pamela Ronald and her husband, organic farmer Raoul Adamchak published Tomorrow's Table, a book-length plea for a marriage between genetic engineering and organic farming. "Agriculture needs our collective help and all appropriate tools," they wrote, "if we are to feed the growing population in an ecological manner" (Ronald and Adamchak 2008, p. 167). Ten years later, biotechnology's compatibility with agroecology became a lightning rod for the Committee on World Food Security, whose High Level Panel of Experts (HLPE) was charged with assessing agroecology's contributions to sustainability, food security, and nutrition. Its final report, published in 2019, didn't as much settle the debate as prime the stage for the UN Food System Summit of 2021, where gene editing and agroecology were proposed as part of a diverse and inclusive toolkit of innovations for farming and food. "Innovation is key for agroecology," said Swiss agronomist Urs Niggli at a pre-Summit event in July. "It's about institutional innovation, social innovation, market innovation, innovation in food consumption, eating behavior, in 
circular economies, and also of technologies such as precision farming, digital tools, and molecular sciences in breeding" (UNFSS 2021).

The notion that genetic engineering and agroecology can complement each other is communicated in both scientific literature and public-facing media. For example, in a study published in 2020, researchers at Wageningen University and Research concluded that "genetic engineering and agroecology certainly have synergy in the context of agroecology as science, when applied to making crops less vulnerable to pests and diseases and when combined with cultivation using IPM" (Lotz et al. 2020). More publicly, in her 2015 TED Talk, Ronald made complementarity personal: "Really? An organic farmer and a plant geneticist? Can you agree on anything? Well, we can, and it's not difficult, because we have the same goal. We want to help nourish the growing population without further destroying the environment" (Ronald 2015). Gene editing has extended these prospects and claims yet further. In the popular-science outlet, The Conversation, Rebecca Mackelprang (2018) argued, "I am a plant molecular biologist and appreciate the awesome potential of both CRISPR and genetic engineering technologies. But I don't believe that pits me against the goals of organic agriculture. In fact, biotechnology can help meet these goals."

The complementarity narrative has obvious allure. With GMOs widely recognized as among the most polarizing of all topics in food systems debates (Bennett et al. 2013; Stone 2017; Macnaghten and Habets 2020), a rapprochement in the age of CRISPR appeals to scholars and practitioners seeking both analytical and real-world consilience. In theory, bridging genetic engineering and agroecology could enable these communities to develop mutually beneficial research programs, lobby for synergistic policy support, and build coalitions across wider constituencies to overcome obstacles to achieving sustainable food systems. In practice, many scholars and social movements argue that modern biotechnologies disrupt, marginalize, and/or otherwise conflict with agroecological approaches (Vanloqueren and Baret 2009; Holt-Giménez and Altieri 2013; Levidow et al. 2014; Nyéléni 2015). Several key agroecological principles, their analyses suggest, are either unmet or actively violated by the sociotechnical systems that biotechnology emerges from and reinforces. These principles include biodiversity renewal, synergy between food production and ecosystem function, co-creation of knowledge, protecting rural livelihoods, supporting cultural and food traditions, and even under certain circumstances, achieving input reductions (HLPE 2019).

The stakes, meanwhile, for the compatibility question grow ever greater. In what has been described as a "battle for the future of farming" (Anderson and Pimbert 2018), it has become evident that twenty-first century biotechnology dovetails not only with intellectual property and trade liberalization of the corporate food regime (Pechlaner and Otero
2008) but with the rise of digital agriculture, artificial intelligence, robotics, and other elements of so-called "AgTech." In this nexus, both agroecologists and biotechnicians face new and renewed questions of platform ownership, data privacy and data justice, landgrabbing, labor displacement, and control over what it means to be a farmer and what it means to farm (Fleming et al. 2018; Rotz et al. 2019; Carolan 2020; GRAIN 2021).

This paper, then, is an attempt to get underneath the complementarity question. I do not empirically survey gene editing's potential risks and benefits for biodiversity, ecosystems, and different communities of people, all possible ways to assess gene editing's alignment with agroecology. Rather, I focus on the epistemic assumptions and ontological fault lines the question illuminates. What kinds of political, social, and philosophical divergences does complementarity reveal? How does history help us uncover contradictions that complementarity embeds? Under what conditions might CRISPR be compatible with agroecology, if it is not compatible now?

\section{Brief background: CRISPR and agroecology}

Since 2012, CRISPR/Cas genome editing technology has taken the biology world by storm, transcending earlier limits of genetic engineering, igniting ethical debates over geneedited humans, and opening new frontiers for agricultural intervention. With CRISPR/Cas, scientists are able to target, modify, regulate, and mark genomic loci of a wide array of cells and organisms. RNA-guided cleavages in the DNA of a host organism trigger cellular repairs which can result in a variety of genetic changes, from full gene knockouts to small sequence substitutions to insertions of cis- or transgenic DNA (Doudna and Charpentier 2014). The organismal plasticity of the CRISPR/Cas system-it appears to work across kingdoms, in any organism in which it has been tried-raises many interesting prospects for agricultural applications, including in plants, livestock animals, soil bacteria, insects, and fungi. Such uses remain primarily in "proof of concept" and piloting stages, but as US and European regulators revise biotechnology governance frameworks to account for gene editing, many types of gene edited organisms are expected to enter commercial markets (Kuzma and Grieger 2020; Macnaghten and Habets 2020).

Agroecology, as a science, practice, and social movement, has long had a tense relationship with technology and biotechnology. As early as the 1930s, Russian scientist Basil Bensin, in one of the first formal studies of "agroecology," described what he saw as indiscriminate use of technological inputs. Observing that farmers were too often convinced by organized advertising campaigns featuring tractors, fertilizers, and high-yielding seeds, he argued that 
these capital-intensive inputs were often inappropriate for local needs (Gliessman 2013). By the late 1970s, Indigenous scientists in Mexico were spearheading agroecology programs in resistance to Green Revolution technological interventions, promoting a science that did not displace native agrobiodiversity with seed-chemical packages but rather relied upon complex innovations underfoot: where networks of wild and cultivated organisms shape, and are shaped by, local knowledge, language, territory, and cultural memory. (Hernández Xolocotzi 1985; Altieri and Merrick 1987).

Since the turn of the millennium, scholarship has recognized an evolution of agroecology from being primarily engaged with farm-level practices to encompassing "the ecology of the entire food system" (Francis et al. 2003). In this transition, some things have not changed: Agroecology's challenge to industrial technology remains based on principles of enhancing biological interactions, recycling of ecosystem services, and knowledge-intensive practices thereby curbing dependency on off-farm inputs (Altieri 1995; Kremen and Miles 2012). At the same time, the wider food systems scope has extended agroecologists' confrontation with technology to intellectual property, trade agreements, industry concentration, and larger political-economic structures of the colonial-capitalist food system.

To be sure, the agroecology community is non-homogenous: some agroecologists principally view agroecology as an empirical, natural science field of study while others view agroecology as a normative paradigm for food systems transformation (Méndez et al. 2013). Still, these intra-field divergences have mattered little in the age of GMOs. As long as the majority of GM crops were herbicide-tolerant or insecticidal versions of soy, maize, cotton, and canola, most agroecologists found little value in the GM portfolio. Yet gene editing, we are told, is not just any old biotechnology. CRISPR is different. It needn't follow in GM's footsteps of Roundup Ready crops, clearly beneficial for vendors of weedkillers. With the right edits, researchers could, for example, generate crops that reduce pesticide use (Schultink et al. 2017; Lotz et al. 2020), increase nutrientuptake efficiency (Wang et al. 2021), and even change core branching and fruiting structures (Lemmon et al. 2018) or photosynthetic pathways (Khumsupsan et al. 2019) to boost crop yields. Such innovations, proponents say, could greatly benefit smallholders and diversified farmers, including in poor countries (Mackelprang 2018; Fister et al. 2018; Lotz et al. 2020). Moreover, the technology could be open source and available to all, giving critics concerned about corporate monopolies reason for optimism (LaManna and Barrangou 2018). Gene editing, in this view, is complementary toeven synergistic with-agroecology as long as both communities remain open to the possibility.

Recent work by Clément and Ajena (2021) used the FAO's 10 principles for agroecology as a starting point for assessing new agricultural technologies like CRISPR. My project takes a different approach, unpacking the politics in asking about complementarity, including what it means, who is posing the question, and who gets to respond. To begin, I sketch the epistemic foundations of science and technology that organize different notions of evidence used in agroecology and genetic engineering. On this basis, I explore 8 angles of the compatibility question, including: (1) technological neutrality, (2) "root cause" problems, (3) working with nature, (4) encoding racism, and dilemmas of (5) ownership and (6) access. These questions, I argue, require a reckoning with (7) ontologies of colonialitymodernity, which help us get underneath-and beyondthe complementarity question. Finally, I offer (8) a framework for thinking about and working toward technology sovereignty.

The ideas I lay out here have emerged in autobiographical time-through roughly 20 years of working in the field of biotechnology, first as a microbiologist, later as a science journalist, and currently as a social scientist combining Science and Technology Studies, political ecology, political economy, and decolonial approaches in studies of agroecological transformations. More proximately, my observations have been informed by interviews with gene editing researchers and advocates conducted between 2018 and 2020 at the University of California. I have also participated, in person and remotely, in numerous conferences, workshops, and webinars on the subject of agricultural technology, gene editing, race \& AI, and agroecological innovation. A literature review of papers on gene editing in agriculture and underlying issues informed my analysis, alongside ongoing studies of agroecology politics in the international arena. Importantly, this work is shaped by my lived experience as the mestiza daughter of Peruvian Quechua and Dutch parents, a hybridity that doesn't allow me to "see both sides" as much as it compels me to resist quick syntheses or points of closure.

$* * * * * * *$

\section{Epistemic foundations of science and technology}

Technology can be, and has been, defined in many ways, including as a "practical application of science and engineering to a wide range of real-world problems," "the practical application of knowledge especially in a particular area," "a capability given by the practical application of 
knowledge," and "a manner of accomplishing a task especially using technical processes, methods, or knowledge."

Yet technologists ${ }^{1}$ and agroecologists often have very different understandings of science as a sphere of knowledge production. Simply put, technology developers (like many scientists in the Western tradition) tend to privilege science based on principles of positivism. Positivist approaches contend that all genuine knowledge is either axiomatically true, is derived from direct experience of natural phenomena, or is testable by experimental design. Positivism favors information gleaned from experiments where conditions are strictly defined and often radically simplified compared to real-world contexts. Testing of falsifiable hypotheses produces verified data, and this data, when interpreted through reason and logic, provide the empirical basis of evidence in a positivist view. What is real and "true," therefore, consists of phenomena that can be distilled to clearly defined and generalizable variables via deductive research and hypothesistesting. Gene editing has largely been developed by scientists and (genetic) engineers within the positivist paradigm. ${ }^{2}$

Agroecology began its Western scientific life as a positivist pursuit, at least for early enunciators of the "agroecosystem" as a field of study (eg., Tischler 1965; Odum 1969). Already by the 1950s, however, agroecologists like Efraím Hernández Xolocotzi were using their training in ethnobotany to lead extensive field collections of the immense agrobiodiversity present in the fields of local Mayan farmers (Gliessman 2013). Agroecological knowledge, at least implicitly, was understood to be produced in relation to Indigenous communities and working farmers-and became a form of resistance to the colonizing logics of World Bank projects for agricultural "improvement." Today, agroecology is highly transdisciplinary in nature, meaning it emerges through the entanglement of multiple forms of knowledge production, including scholarly disciplines that are non-positivist in orientation (eg. critical race and ethnic studies, Science and Technology Studies), practitioner and rural communities' knowledge, and Indigenous ecological knowledge.

The ongoing decolonial turn for agroecology has meant not only decentering science as the exclusive realm of knowledge production, but also decentering humans as exclusive agents of making knowledge. Here, agroecology has been principally guided by Indigenous cosmologies that dissolve

\footnotetext{
1 "Technologists" here describes those actors practicing and steeped within a modernist notion of creating, owning, and applying technology. But as will become apparent later in this paper, agroecology also involves and can support a wide array of technologies.

2 Throughout this paper, I use "gene editors" to refer to scientists who perform gene editing and to the wider community of research, policy, and media advocates for gene editing in agriculture. "Agroecologists" refers to researchers, practitioners, and social movement actors who comprise the agroecology community in a broad sense.
}

the binaries coloniality-modernity has imposed between nature/human (see also part 8). In recent years, multi-species studies and the concept of "conviviality" (Illich 1973) have posed an energetic alternative to the Anthropocene, foregrounding the more-than-human world (de la Cadena 2015; Tsing et al. 2020) and offering agroecologists additional grist for thinking outside industrial production and the toxicities and violence unfolding on extractive frontiers. Of course, for agroecologists trained in Western plant and soil sciences, the more-than-human world was never in the shadows. Indeed "biodiversity" tended to eclipse the social, referring only to the abundance and variety of non-human biological life. In response, feminist agroecology has wrapped around the seeming contradictions of the Anthropocene discourse and the people-free nature discourse, both ultimately rooted in separations of human and non-human living worlds. It has foregrounded a practice of entanglement and care (Zuluaga Sánchez et al. 2018). As co-organizer of Alianza de Mujeres en Agroecología, agroecologist Helda Morales (2021, pp. 955-56), writes:

What could we as agroecologists learn from these ways of seeing the world? In my opinion, we need to envision an agroecology that celebrates plurality, diversity (not only of plants and animals, but of people), nonviolence, and love. We need movements and academies that, as Lorena Cabnal puts it, "recover joy without losing indignation."

This indignation, rooted in heteropatriarchy and coloniality, has inspired a revision of the history of agroecology itself. While agroecology's story told through settler lenses typically emphasizes twentieth century trailblazers like Germany's Wolfgang Tischler and US tropical biologist Dan Janzen, agroecologists are now beginning to affirm a different genealogy (Suárez Torres et al. 2017; Giraldo 2018; Pimbert et al. 2021). Indigenous people are easily the world's first agroecologists, having anticipated 'systems thinking' with complex and relational accounts of ecosystems and their co-evolving constituent parts (Vandermeer and Perfecto 2013; Marya and Patel 2021). They are agrarian communities from whom colonizers have stolen land, water, seeds, and corresponding knowledge of the natural worldthe systematic destruction of which Portuguese sociologist de Sousa Santos (2014) calls "epistemicide." Nonetheless, it is Indigenous communities who are today re-awakening a wider understanding, including among settler scientists, of the sustainability intrinsic to living in reciprocity with one another and the land (Figueroa-Helland et al. 2018; Iles 2021). In addition, since the turn of the millennium, agroecologists have increasingly made explicit the "political" in agroecology (e.g. Rosset and Altieri 2017; González de Molina et al. 2020), recognizing the knowledge that emerges from organizing, by and with peasant, Indigenous, and other 
agroecological social movements. This collective and relational orientation extends what STS has long held to be true: Science cannot help but be political, as it is a social practice, resulting in necessarily partial, imperfect, and non-objective accounts of the natural world.

Among other things, the above epistemic differences means that agroecologists and gene editors tend to have different baselines for understanding what constitutes "evidence." For most gene editors, evidence is gleaned by professionally trained researchers, trained in methods of systematic study design, statistical significance, and replicates under varying conditions to produce generalizable knowledge. This model of research, now dominant in university institutions globally, arose in Europe during the patronage of the Royal Society of London in the 1700s. By formalizing a distinction between technical knowledge of elites and the common-sense know-how of peasants and artisans, the Royal Society secured its place as an institution equipped to combine knowledge and power (Shapin 1994). Achieving mastery over nature through greater technical knowledge gained particular prominence in fields like engineering, of which genetic engineering is a part, and can be seen in the Latin ingenium (c. 1250), meaning "innate quality, especially mental power, hence a clever invention."

By contrast, though agroecology can be, like gene editing, richly experimental and hypothesis-driven in nature, it tends to be place-based, culturally-grounded, and immersed in (messy) everyday life. Much agroecological evidence is produced through methods and theories that intentionally trouble lay/expert divides, including oral history, citizen and community-based science, Participatory Action Research (PAR), and/or Indigenous and traditional ways of knowing. Rather than seek mastery over nature, these methods intentionally seek learning with and from nature's evidentiary uncertainty. For example, illustrating the difference between control and convivir (living with), for the Indigenous Quechua women of highland Peru, plants and other organisms are not so much acted upon as they are active agents in cocreating medicinal, food, and territorial knowledge through relations of care, labor, metabolism, and coevolution. In fact, writes Marisol de la Cadena in Earth Beings, a participatory ethnography of the Quechua people, "there is no necessary difference between humans as subjects of awareness and places as objects of awareness, for many of the 'places'... were also "sentient"' (2015, p. 101).

In sum, where gene editors tend to authenticate evidence via a precise scientific method, increasingly many agroecologists align with STS, Indigenous, and Black feminist perspectives in arguing that there is no single valid methodology in science. Rather, a diversity of critical methods will help science ultimately achieve a "strong objectivity" (Harding 2007), greater capacity to self-critique, and enhanced prospects of connecting explanatory power to liberatory power (Liboiron 2021). This includes methods of imprecision and relationality - academic forms mixing with storytelling, dance, poetry, song, and anticolonial chronologies-that effectively interrupt knowledge systems which seek to observe, index, and discipline subaltern subjects (Da Silva 2014; McKittrick 2021).

Such divergences can make the dovetailing of CRISPR and agroecology hard to fathom without a significant shift in the core scientific tenets of one field or the other. Yet, this hasn't stopped biotech enthusiasts from asserting that gene editing has much to offer agroecological farming. Working on and through the particular assumptions these claims contain will be key to avoiding fruitless polarization while gleaning lessons from both gene editing and agroecology communities.

\section{Technological neutrality, "win-wins," and socio-technical systems}

A core assumption upon which most arguments in favor of complementarity rest is technological neutrality. Technologies are neither good nor bad, the argument goes, and "technology is not the problem-it's the applications to which technology is put." This argument is double-edged insofar as its speakers recognize both beneficial and adverse effects of technology; therein, it seems utterly reasonable and disarming. At the same time, tech neutrality conflates "technology" as an abstract concept with technology that de facto exists. For example, GM crops are often described as having multiple potentially beneficial uses-including ones that don't promote agribusiness or pollute the planet (Johnson 2015). Applications are what matter, these arguments go, and rational people should discriminate on a case-by-case basis. Yet these analysts seem to lose the crumbtrail of empirical evidence they urge is required. The fact that $99 \%$ of GM crops have been developed with either herbicide-tolerance or $\mathrm{Bt}$ insecticide - and almost all acreage is commodity crops of soy, corn, cotton, and canola (ISAAA 2019)—is treated as circumstantial. If anything, these patterns indicate that incentive structures for tech innovation are anything but neutral. Yet the trope of neutrality unmoors biotechnology from path-dependent real-world circumstances. By emphasizing what might be rather than what, under predominant conditions of agroindustry power, actually exists, the abstraction strips away history and systems and leaves only tools.

In this way, biotechnology tools can also seemingly be transplanted into agroecological systems to achieve the best of both worlds: a "win-win." Yet win-win logics obscure many things, not least of which is a violation of basic principles of political ecology. Under colonial-capitalism, development proceeds through uneven processes of creation and destruction. Winners don't occur without losers-and most 
wins actively produce losses. In agricultural research, the development of modern biotechnological science has worked to underdevelop agroecology research, science, and innovation since the 1980s. In a history that has been detailed elsewhere (see: Buttel 2005; Warner et al. 2011), US land grant universities saw their community-based biological control programs systematically defunded, cooperative extension for farmers in agroecological methods phased out, and world-class departments and research centers for agroecology effectively dismantled. The win-win trope is as true at larger scales of global agriculture development, where mainstream analyses seek answers for African food insecurity in the failures of African culture, work ethic, and intellect-in a lack of knowledge, science, and "development" (Rodney 1972 [2018]). These accounts not only ignore the presence of sophisticated African agriculture and social order prior to colonization, they deny that European and US advance was only possible due to Africa's rapacious underdevelopment by imperial powers.

As all frames do, "win-win" framings hide processes and relationships outside the frame while focusing attention on those within. With gene editing, often obscured is the fact that technologies are imbricated in larger socio-technical and political-economic systems (to leave aside ontologies for the moment). In the case of Africa, for example, these larger socio-technical systems involve regional and national seed laws, marketing rules that favor uniform and standardized seed varieties, and patent-like "plant breeders rights" that countries adopt to fulfil World Trade Organization requirements (Wattnem 2016). Such changes are supported by organizations like the African Agricultural Technology Foundation, which was born in 2001 out of negotiations between the Rockefeller Foundation and corporations including Monsanto, Dupont, Pioneer, and Syngenta to promote GM seeds in Africa (Boadi and Bokanga 2007; Belay and Mugambe 2021). In short, science and technology inevitably exist within regimes of knowledge-making, material infrastructures, and institutional norms of governance and regulation (Jasanoff 2004). They exist within markets and politics, which today entails a world order predicated on the assumption that human wellbeing is best advanced by liberating individual entrepreneurial freedoms and skills within an institutional framework that favors strong private property rights, free markets, and free trade (Harvey 2007). These layered systems tend to "lock in" certain kinds of knowledge making and technology while they "lock out" others-and agroecology and genetic engineering have a fraught history here (Vanloqueren and Baret 2009).

CRISPR, unless extricated from this context, will continue to lock in Malthusian narratives of "feeding the world." It will continue to lock in intellectual property (IP) rights on seeds, international trade agreements that enroll countries into IP protocols, and economic policy that promotes overproduction of cheap food in the US and Europe while encouraging the Global South to trade progress on food sovereignty for liberal market dependency. It will continue to work from the colonialist and heteropatriarchal assumption that the world needs rescuing and surely "we" (scientists and technologists) are the ones to do it. Importantly, CRISPR is not only bound by these trappings-making it hard to perform an extraction - it also embodies and propagates these colonial-capitalist processes and values. If CRISPR is to be compatible, then, with agroecology, its proponents must engage with the win-lose dynamics of technology's history and offer a credible account for how the tools of worldmaking can somehow be neutral.

\section{Working with nature}

Key to understanding the discursive field into which complementarity has entered is the broad consensus among scientists that the current food system is unsustainable (Willet et al. 2019; FAO et al. 2020). While glyphosate and other pesticides compatible with GM crops continue to penetrate new markets globally (Werner et al. 2021), many gene editors have pivoted away from chemical-intensive paradigms. The CRISPR R\&D pipeline now features a wide range of sustainability characteristics: from blight-resistant grains that curb pesticide use (Oliva et al. 2019) to rice with enhanced potassium uptake efficiency for reducing fertilizer application (Wang et al. 2021) to de novo domestication of wild Solanum pimpinellifolium in order to re-diversify the tomato family (Zsögön et al. 2018). "Efficient plant breeding," say authors of a recent Plant Cell review on genome editing, "can generate elite varieties that will rapidly replace obsolete ones and address ongoing challenges in an efficient and sustainable manner" (Miladinovic et al. 2021).

In addition, several CRISPR projects are taking earlier critiques to task. For example, researchers with the Cassava Genome Editing Project, based at the University of California's Innovative Genomics Institute, are using CRISPR to gene edit cassava (also known as yucca). Since cassava roots naturally produce the precursor of cyanide, families ordinarily remove these toxins during post-processing. However, say researchers, many people are eating insufficiently processed cassava- "a problem particularly in parts of sub-Saharan Africa that have experienced drought, famine, and instability" (Murdock 2020; see also Gomez et al. 2019). Alongside cassava, crops like sorghum and cacao have become the new targets of "pro-poor" plant breeding (Innovature 2019; Liu et al. 2019; Phelps 2019), marking a pivot from GM's reputation as primarily involving largescale commodity crops for biofuels and livestock feed. New initiatives typically describe adapting CRISPR crops to local 
conditions and prioritizing varieties that are "a major source of calories" for smallholders (IGI 2021).

Questions of complementarity with agroecology feature prominently here. Whereas agroecologists have frequently claimed that GMOs do not feed the world, gene editors are explicitly shifting to food security crops. Whereas agroecologists have justifiably criticized the toxic legacy of glyphosate, dicamba, 2,4-D and other herbicides linked to GM crops, gene editors are now rolling out traits that, they say, will shrink the ecological footprint of agriculture rather than expand it. If gene editing is going to now "work with nature," then perhaps there is room for convergence with agroecology?

"Nature-positive production" suggests so. Nature positive production is a new umbrella term for an array of approaches described in a report written for the UN Food Systems Summit as "characterized by a regenerative, non-depleting and non-destructive use of natural resources" (Hodson et al. 2021). It is also emerging as the latest attempt in international science-policy spheres to argue for complementarity between agroecology and gene editing. At a pre-summit event in July 2021, co-author and UNFSS Scientific Group member Urs Niggli argued enthusiastically that naturepositive production is an intrinsically catholic approach: "it doesn't exclude any kind of innovation as long as they serve the purpose of establishing comprehensive food systems" (UNFSS 2021).

Putting aside the muddiness of "comprehensive food systems," nature-positive production is a term without clear reference points in the scientific literature or documentation of successful applications. The term appears in World Economic Forum reports from 2020 (WEF 2020), building on earlier documents where the Forum advanced what it calls the "Fourth Industrial Revolution," including major shifts in thinking about the value of nature and for new, highly profitable business models enabled by digital and biotechnologies (WEF 2018). Close scrutiny of the tenets of nature-positive production suggest it belongs to a family of related concepts that the High Level Panel of Experts of the UN Committee on World Food Security have identified as part of the Sustainable Intensification paradigm. Why does this matter?

Sustainable Intensification (SI) was first amplified by the Royal Society in 2009 in an influential report urging a need to increase global food production without damaging societies or the environment. Since that time, the discourse has matured, with Garnett et al. (2013) calling for "a more sophisticated definition" and a clarification of the logics on which SI rests. These pillars include: (1) the need to increase food production; (2) increased production must be met through higher yields because increasing the area of land in agriculture carries major environmental costs; (3) sustainability requires as much attention as productivity; (4) sustainable intensification denotes a goal rather than a specific classification of which agricultural techniques to deploy.

Agroecologists have, in turn, met each of these claims with counterproposals. A fundamental critique rests on asking whether, a priori, more food needs to be produced or whether the solution to the problem of hunger and malnutrition lies in distributive justice (Bernard and Lux 2017). Agroecologists have tended to reject the premise of global yield mandates, pointing to their origins in classist and racist Malthusian tenets (Chappell 2018) as well as unscientific estimates of future food demand (Tomlinson 2013). Agroecologists frequently emphasize that although the actual number of people suffering from hunger is contested, it remains clear that the global production of kilocalories exceeds the current need for the planet's population-yet clearly not everyone is being fed (Badgley et al. 2007; FAO et al. 2020).

An equally fundamental question is that of "nature." The emphasis of SI on efficiency and higher yields shares many aspects of "land sparing" in conservation science, an approach focused on boosting agricultural yields to allow preserving non-farmed areas for wildlife (Fischer et al. 2008). This cultivated/wild dichotomy makes land sparing easily compatible with optimization methods that attempt to allocate land uses in the most efficient way. By increasing agricultural output levels per area unit while reducing natural (e.g. land and water) and synthetic (e.g. fertilizers, pesticides) inputs, resources can be used more efficiently and area under cultivation can be contained. In short, the underlying premise of SI is that "nature" is separate from "agriculture," and farming practices - and by extension, farmers, peasants, and Indigenous communities - are intrinsically corrosive to nature's ecological integrity.

By contrast, agroecology shares many aspects of "wildlife-friendly" models of conservation. These models emphasize heterogeneity, resilience, and ecological interactions between farmers and unfarmed areas (Fischer et al. 2008). While newer studies have suggested that sparing/sharing may not be an either/or proposition (Kremen 2015), the underlying point is that different scientific traditions underlie the two approaches. The agroecological approach assumes, at base, that agricultural landscapes can "work with nature" not by being spatially separate from nature but by incorporating biodiversity and by supporting beneficial ecosystem interactions across scales (Chappell and LaValle 2011; Kremen and Merenlender 2018). The agroecological view also holds that biodiverse landscapes, far from being untouched, are richly inhabited by peasants, Indigenous peoples, and small-sized family farms whose behaviors and practices profoundly shape-and "produce"-nature (Hecht 2010; Perfecto and Vandermeer 2010). A peasant and Indigenous perspective on producing nature, moreover, contains multitudes: nature herself expresses agency in organizing the 
complex, multi-species assemblages that make agriculture and surrounding processes work.

Considering these differences between SI and agroecology, it is significant that SI has long held that "no useful approach or technology can be ignored" (The Royal Society 2009, p. 47). This notion has evoked criticism from agroecologists within the scientific community as well as from environmental, peasant, and justice organizations who perceive SI as a 'Trojan horse' primed to introduce many capital-intensive technologies into previously untapped markets (Collins and Chandrasekaran 2021; Altieri et al. 2017; Nyéléni Newsletter 2019). "Through the SI discourse," agroecologist Pablo Tittonell has argued (2014, p. 54), "biotechnology found a new avenue to promote itself as a cure to world hunger. They managed to engrave in part of the collective consciousness the idea that the world will not be able to feed itself without genetically modified crop cultivars."

In 2019, the UN High Level Panel of Experts put brakes on this putative Trojan Horse by clearly distinguishing agroecology from SI. In one of the most comprehensive scientific assessments to date of approaches to sustainable food systems, the HLPE clearly distinguished SI (and related approaches) from agroecology (and related approaches), suggesting key differences in their assumptions, priorities, and emphases. Agroecological approaches, it said, "aim to be more transformative." They "address not only ecological and health impacts of food systems but also power asymmetries and socio-economic inequalities" (HLPE 2019, p. 64). That the UN Food Systems Summit sought to elide these differences, resurrecting SI in a new skin of "nature positive production" matters for our understanding of complementarity. Nature has, in many ways, become the new watchword for gene editing, bringing it into proximity with agroecology. It remains uncertain if this vision of complementarity will sustain nature or, by contrast, will sustain power asymmetries that stabilize the status quo.

\section{Root-cause problems. Do gene editors and agroecologists have a shared analysis of the underlying problem(s)?}

Given that agroecologists and gene editors will continue to grapple together, and separately, with the challenge of "sustainable food systems," it's worth pressing the point further: to what extent do these actors share not simply a goal of sustainability but a common understanding of what is to be sustained? Do they share an analysis of the underlying logics and forces that need changing? For example, led by peasant and Indigenous movements, agroecologists are now converging around a diagnosis of root cause problems being co-located in a web of ideological and institutional "lock-ins," at the center of which is the concentration of corporate, governmental, and epistemic power (e.g., IPESFood 2016; Gliessman 2020). Complementing this analysis, a longer duree agroecological view situates the origins of ecological, human health, and food system crises in old and ongoing violences of colonial capitalism (Giraldo 2018; Marya and Patel 2021). By contrast, many scientists and engineers work from an understanding that unsustainability principally derives from errors of efficiency and lack of scientific knowledge/data. Accordingly, they will tend to focus on technical aspects of the agricultural system, seeking to achieve greater yield per unit input, maximize labor efficiency, and reduce pollution and other environmental losses through fewer or more precise applications of water, fertilizers, and pesticides.

The issue, then, of focusing on "symptoms" versus rootcause problems is both practical and ideological. It is very possible that agroecologists and gene editors may find common ground in appraising symptoms: for example, in California, drought and saltwater intrusion in coastal zones are critical problems for sustaining agriculture. But they will likely part ways in ascertaining the level at which such a problem is best addressed. Whereas a biotechnologist might say, "Let's gene-edit a crop that withstands water scarcity and salty soils more effectively," an agroecologist might propose, "Let's address why we are growing thirsty crops here in the first place: what kinds of plants are native to this landscape? What of settler occupations of Indigenous lands, the reengineering of hydrological landscapes to make mass horticulture viable, and the agribusiness power shaping water access and governance today?" Agroecologists might seek advice from and collaboration with the descendants of the California tribes who once grew crops like taboose (Cyperus esculentus, cultivated for its wild tubers) and nahavita (Dichelostemma capitatum, gathered for its edible $\mathrm{corm}^{3}$ ) in these arid regions.

To take a more recent example, in May 2021, the UK's Rothamsted Research applied for a permit to field test wheat that has been gene-edited to contain less asparagine, an amino acid that becomes the carcinogen acrylamide when cooked at high temperatures (Rothamsted 2021; Raffan et al. 2021). The research institute explained that the "low acrylamide" wheat was modified using CRISPR to reduce the production of this chemical, which may cause cancer. Agroecologists looking at the same problem would point out that naturally low asparagine wheat varieties have long been available to farmers (Curtis et al. 2019). They would note that sulfur deficiency in soils leads to raised levels of asparagine in the crop (Curtis et al. 2018) —and that sulfur deficits

\footnotetext{
${ }^{3}$ Corms are vertical, fleshy, underground stems that act as a foodstorage structure in certain seed plants. Sometimes called solid bulbs, or bulbo-tubers, corms are distinguished from true bulbs and tubers.
} 
are becoming increasingly common worldwide because of lower atmospheric sulfur deposition (from switching to lowsulfur fuels) and agricultural intensification, namely high biomass export and higher-yielding crops that denude soils of minerals more rapidly (Lucheta and Rodrigues Lambais 2012; Raffan et al. 2020).

Root-cause analyses are perhaps nowhere more important than in Africa, ground zero for the new Green Revolution, a proposal by the Gates Foundation, the US State Department, the Rockefeller Foundation, and multiple private sector groups, to "catalyze agricultural transformation" needed to accelerate progress toward sustainable development on the continent. Biotechnologies are a key part of an agricultural strategy aimed at harnessing a food market in Africa whose value is projected to increase from US $\$ 313$ billion in 2010 to US\$1 trillion in 2030 (AGRA 2021). Bill Gates himself has attempted to preempt claims of neocolonialism. Describing how genetically engineered seeds and other technology would solve hunger in African countries, Gates (2015) argued: "it's a sovereign decision. No one makes that for them." Yet as leaders of the Alliance for Food Sovereignty in Africa (AFSA) have pointed out, the Gates Foundation commands massive resources which "have had an outsized influence on African scientists and policymakers, with the result that food systems on our continent are becoming ever more market-oriented and corporate-controlled" (Belay and Mugambe 2021).

AFSA's concerns have old roots. In his magnum opus, How Europe Underdeveloped Africa, Guyanese scholar Walter Rodney (1972 [2018], p. 26) argued that "Mistaken interpretations of the causes of underdevelopment usually stem either from prejudiced thinking or from the error of believing that one can learn the answers by looking inside the underdeveloped economy. The true explanation lies in seeking out the relationship between Africa and certain developed countries and in recognising that it is a relationship of exploitation." For Rodney, as for other Pan-Africanists and decolonial theorists, the way to understand development is through its intrinsic and necessary relationship to exploitation of the colonies. When citizens of Europe owned the land and the mines of Africa:

[T]his is the most direct way of sucking the African continent. Under colonialism the ownership was complete and backed by military domination. Today, in many African countries the foreign ownership is still present, although the armies and flags of foreign powers have been removed. So long as foreigners own land, mines, factories, banks, insurance companies, means of transportation, newspapers, power stations, etc. then for so long will the wealth of Africa flow outwards into the hands of those elements (Rodney 1972 [2018], 27).
In other words, in the absence of direct political control, Africa's agroecology and the labor of her people will produce economic values which are inevitably lost to the continent. These arguments have been carried into twentyfirst century studies of African agroecology, which find, for example, that food sovereignty in Malawi was eroded first by British colonialism and later through "liberalization and privatization of the seed system and the dominant role of the government's subsidy programs in influencing available seed types" (Bezner Kerr 2013, p. 868; see also NyantakyiFrimpong et al. 2017; Rock 2019). Current estimates suggest that farmer-saved seed makes up $60-80 \%$ of all seed used by farmers in sub-Saharan Africa (Bezner Kerr 2013, GRAIN and AFSA 2019), suggesting a likely decline from two decades ago, when regional studies found that non-farmer-saved seed accounted for less than $15 \%$ of all seed used (David and Sperling 1999). In Malawi, as in many African countries, the intersection of class and gender dynamics, as well as access to land and the role of the state in seed production and distribution, play a critical role in food sovereignty. All have been shaped by colonialism and its ghosts.

The rub, of course, is what to do now. Root-causes being deep and very old, a logical question that gene editors can and do ask is: what about urgent crises we are facing today? Is it not better to use the best technologies available to deal with hunger, malnutrition, even cyanide poisoning, while also doing the longer-term work of decolonizing? It helps here to distinguish between symptom and disease. While in theory, symptoms-level approaches may temporarily stymie a given problem, the risk is that financial investments, human resources, training and education go materially to serve stopgap solutions while structural malaise remains untreated. In another sense, symptom-level solutions often fail even as palliative, because as Rodney and others show, those resources always come from somewhere, and this ecological and social debt preconditions further ailment.

What solutions, then, might be closer-at-hand for immediate crises facing people and planet? Agroecologists argue they lie in recognizing what root-cause analyses unveil: the agroecological traditions, practices, and knowledges that colonialism trod over and that could be supported and reinvigorated today. Prior to the arrival of the Portuguese, Carney's work has shown (2001), smallholders in West Africa had domesticated their own variety of rice, O. glaberrima. Indigenous soil and water management practices, of which women were often the knowledge keepers, permitted a sophisticated cultivation of rice under differing climatic and environmental conditions. "By the fifteenth century," Rodney (1972 [2018], p. 44) writes, "Africans everywhere had arrived at a considerable understanding of the total ecology —of the soils, climate, animals, plants and their multiple interrelationships..." In some areas, pre-colonial African farmers were using methods such as terracing, crop 
rotation, green manuring, mixed farming, and regulated swamp farming.

With such practical solutions unveiled by root cause inquiries, why do they remain ignored or glossed by gene editors? The answer prompts our attention to the intersections of white supremacy and science.

\section{Racism encoded}

Critical researchers of the Green Revolution have documented how "white science" contributed to notions of genetic purity in plant breeding: by framing Native seeds as impure, low-yielding, and primitive, scientists legitimated the replacement of local cultivars with "superior" high-yielding seed varieties, and sought to hybridize lines of corn so as to whiten the offspring, progressively erasing their indigeneity (Eddens 2019). Indigenous STS scholars have documented similarly specious assumptions in human genetic science, where the same racist science that informed white definitions of tribes in the nineteenth century continues to shape DNA testing protocols of the twenty-first century (Tallbear 2013). Black scholarship has also taken genetics to task: connecting ancestry testing to slave histories and racial politics, sociologist Alondra Nelson (2016) traces how a popular yearning for African-Americans' "lost roots" led to DNA as magic and metaphor. Genetic code, she shows, can serve as a vessel for dreams about the past, present, and future, offering (often shallow) promise of racial reconciliation, repatriation, and reparations.

Students of Black and Native history need little reminder that racism courses through US agriculture and food. From rice plantations of the Carolinas to white settlement under the Homestead Act, a nation-state built on stolen land and enslaved labor does not easily resolve relations with Black, Indigenous, and brown people (Carney 2001; Dunbar-Ortiz 2014). Gene editing is happening in 2021 , a time of agitation for \#LandBack, seed rematriations, land reparations, and labor organizing for BIPOC food workers and farmworkers. It's a time when this larger political ecology is important for anyone researching or making technology in agriculture, including the engineering of microbes, animals, insects, seeds, and, possibly, people.

Importantly, much agricultural gene-editing work will look benign and inoffensive. Much of it will look neutral, "normal," and objective by the standards of discriminatory systems of previous eras. However, as STS scholar Ruha Benjamin (2019) argues, that is precisely the power of the "new Jim Code," where "the employment of new technologies that reflect and reproduce existing inequalities" escapes scrutiny because, after all, it's just an algorithm. How can algorithms be racist? In a similar vein, Virginia Eubanks (2017) shows how automated systems-designed by people yet ostensibly neutral in operation-control which neighborhoods get policed, which families get welfare, food stamps, and Medicaid, and who is investigated (or not) for child abuse or fraud. A new "digital poorhouse," she suggests, has emerged: While everyone is living under a new regime of data, the most invasive and punitive systems are aimed at poor, Black, and brown communities. Digital farming systems will not be immune from this tendency, nor will gene editing systems where "coding" is, quite literally, how the technology works.

Without stretching the imagination, it's possible to flag a few ways gene editing can be racialized. It can be in the construction of "superior" traits and crops that serve to render Indigenous, Afro-Indigenous, and other traditional varieties as inferior (Saini 2019; Eddens 2019). It can be in the transfer of these "improved" seeds to non-white communities without their full consent or participation (Yapa 1993). It can be in the material displacement of seed exchange networks, the contamination of Native seeds and wild relatives by gene flow, and/or the further consolidation of landholding under "nature positive production" (see Sect. 2). It can also be via extraction of genetic data from landraces without communities' knowledge, let alone permission, to obtain valuable sequence information to engineer this century's prize: climate-resilient crops. Not least, it can extend epistemicide into the CRISPR era through the grooming of BIPOC gene editors who rather than learn about BIPOC agroecological knowledge, historical and present, become spokespeople at decision-making tables already set by elites and public-relations experts increasingly savvy to the politics of inclusion.

The challenge, then, is not simply to lambast the fact that technology is racist. It's to understand how power articulates through information architectures, codes, and technologies that can hide, speed up, and even deepen discrimination behind apparently neutral or benevolent design. It's to ask: how can we build technologies of resistance in the face of anti-Blackness, anti-Indigeneity, and anti-poorness? To borrow from the Otherwise School (2021) "How can we locate technology in these intersecting forces of harm?".

\section{Ownership and beyond ownership}

So far, this paper has explored epistemic schisms that divide many agroecologists and technologists. It has unpacked win-win frames which presuppose technological neutrality, reduce compatibility to techniques, and eclipse the extent to which tools produce losers through their reinforcement of specific, racialized orders and political economies. It follows that no conversation about agroecology/CRISPR compatibility can be complete without addressing ownership and control. At issue here are questions like: Who owns the tools 
of gene editing? Who owns its products? Who controls the data derived from CRISPR's many prospective uses and applications?

In digital agriculture, Rotz et al. (2019) describe potentially promising examples of open source technology and data sharing, where groups working outside the corporate realm of digital agriculture and precision agriculture are attempting to develop scale-appropriate components of digital systems for agroecological and small-scale farmers. For example, entities such as Farm Hack, FarmOS, ISOBlue, and AgriLedger - alongside publicly funded platforms - are, in different ways, working to overcome barriers of corporate competition, data siloing, and proprietary ownership in the interest of farmers. In Europe, groups like the Agricolus and the P2P Lab are working on what they call "smart farming platforms [that] can support agroecological farmers," including open-source tools for small-scale farming (Agroecology Europe 2021). SoilApp, available globally, combines mobile phone technology with citizen science to support farmers in participatory health monitoring. At the same time, as Rotz et al. (2019, p. 218) caution, "while collectivisation via community and user driven assemblages may help to shift farmer dependence away from the corporate food regime, it will not directly address the broader political trajectory of corporate concentration across the agro-food system, nor within agtech specifically."

Gene editing has brought ownership questions into stark relief due partly to struggles over rights to the foundational IP in CRISPR-Cas (Sherkow 2015). While the University of California and the Harvard/MIT Broad Institute battled it out in the courts over claims to the original innovation, the licensing landscape grew increasingly complex, with exclusive and non-exclusive rights to CRISPR components, vectors, activities, and applications swiftly moving into familiar grooves of control by large-scale agro-industry. As early as 2016, according to Egelie et al. (2016), and even though both institutes were offering academic researchers access to CRISPR plasmids free of charge, the commercial licensing landscape for trait and seed development was becoming increasingly proprietary. While academic institutions remained in control of medical applications, "larger industry players, with Dow and DuPont at the forefront, already appear to be more in control of the technology's agricultural and food applications" (Egelie et al. 2016). By mid-2019, Corteva had spun off from the transient merger of DowDuPont and now holds the world's largest portfolio of CRISPR IP, though Syngenta-ChemChina is rapidly catching up. Observers have described an extraordinary funneling of state-funded Chinese CRISPR agricultural research, accelerated by global open access availability, into the jointholdings of the giant Swiss-Chinese company (Cohen 2019).

These trends go to illustrate the complicated, even contradictory, relationship of "open" and "proprietary." While joint licensing frameworks have meant that CRISPR-Cas9 systems are largely free (open access) for the purposes of basic, non-commercial research, this freedom has done little to change the proprietary pipeline of seed development-and could even be accelerating it (see Sect. 6). It's vital for gene editors to understand that for many agroecologists, these IP enclosures ultimately signify a non-starter. To the extent that patents and other forms of IP interrupt the renewability of ecosystem function around which agroecological design is configured, and to the degree they extend the long historical process of value- and knowledge appropriation from in situ farms to ex situ sites of accumulation, they are by definition non-agroecological.

To make complementarity more credible, then, biotechnologists can begin rejecting proprietary norms for their work while also recognizing that open tech still operates within dominant agro-food systems where little else is open or free. Working with communities and movements who have been forging commons alternatives to private property rights across land, water, seeds, food, data, and digital infrastructures (eg. Bollier and Helfrich 2019; Vivero Pol et al. 2019; Sievers-Glotzbach and Christinck 2021), gene editors can help agroecologists confront cross-sectoral proprietary lock-ins of knowledge and materials in global value chains. Going beyond regulating corporate ownership, and even reclaiming ownership at local levels, researchers could ask if "ownership" is a concept that suits either biotech or agroecology well, long-term. Here, inspiration can be drawn from many fields and communities, including the open software and open hardware movements, the right to repair movement, the seed and food sovereignty movements, and food and farming cooperatives. It can come from Native peoples worldwide who are fighting for their lands not because they seek ownership, but because property rights have no rational place in a relational world: where subject/object divides don't adhere and where ecological communities, including humans, "co-innovate" as they grow in, learn from, and adapt to their living environments. What kind of technology could emerge from such multi-agent, collaborative, and coevolutionary cradles? Agroecologists and technologists have room to elaborate this space.

\section{Equity and (problems with) access}

Questions of equity in agricultural technologies frequently center on "lack of access." And for good reason: some of recent history's most important technological projects, like the Green Revolution, reveal stark asymmetries in social access. In places like India's Punjab, a well-endowed district, farmers were better able to capitalize on state-backed irrigation infrastructures and government procurement programs to buffer the falling prices for grain that bumper crops 
inevitably produce (Subramian 2015). Punjabi farmers, first large and later small, had an easier time accessing cooperative extension and synthetic inputs needed to coax yields from "miracle seeds" that Green Revolution science ushered in (Perkins 1990; Patel 2013).

From this read alone, ensuring more access to technology becomes the logical solution. If rich farmer A benefits from access and poor farmer B does not, then making sure that both A and B have access should result in an equitable outcome. However, two problems emerge from this thinking, both of which Green Revolution history also illuminates. First, access to technology needs assessment at scale. Zooming out from the Punjab reveals that $76 \%$ of India's total increase in wheat production was located in just two states, Punjab and Uttar Pradesh, and the majority of its agricultural growth was restricted to 17\% of the country's districts (Prahladachar 1983; Patel 2013). Temporal scale shows further unevenness: decades after the adoption of Green Revolution seed-chemical packages, state support had declined, dragging crop prices below the costs of production, and intensifying farmers' debt. Ecological problems had emerged too, including pesticide pollution, biodiversity loss, and saline and degraded soilseventually resulting in a full-blown agrarian crisis at the intersection of human and environmental health (Aga 2021).

The second problem with the "more access is better" notion stems from the simple fact that unevenness across space is not merely circumstantial-it is relational. As the dynamics of the technological treadmill clearly demonstrate, farmers forced out of agriculture for their inability to stay ahead of falling prices will lose their land to others, whose landholdings thereby expand. Indeed, in Punjab, studies by Sharma (1994) show that from 1953 to 1954, when the bottom $50 \%$ of smallholders owned $0.47 \%$ of the land, the figure temporarily increased to $0.52 \%$ in the early 1960 s before falling to just $0.32 \%$ by 1982 . In other words, landlessness increased in Punjab and poorer farmers saw their share of the land fall. Meanwhile, "middle peasants" saw their share of land holdings rise from 22.69 to $34.19 \%$ of total land held over the same period (Patel 2013). These win-losses of the Green Revolution remind us just how contingent technological change can be, across space and over time. Multiple studies now suggest India was hardly unique in its experience. The greatest AgTech revolution of the twentieth century seems to have succeeded on one "universalizing" count: it exacerbated rather than mitigated existing social inequalities (Wright 2005; Cullather 2010; Stone and Glover 2017).

Access in gene editing has been widely discussed, with some seeing promise in DIY CRISPR kits and other low-cost versions of gene editing systems (Regalado 2015; Montenegro de Wit 2020). As with Green Revolution imaginaries, this frame assumes that greater access to technology automatically brings greater social wellbeing-a fiction that becomes immediately apparent if we substitute "DIY
CRISPR" with "DIY gun" technologies (Greenberg 2018). Most governments, moreover, implicitly recognized the chasm between access and wellbeing when regulating technologies like nuclear energy and weapons; both are governed by dozens of safety protocols and multilateral treaties (Alger 2008) on the assumption that public welfare is better served by restricted access rather than open access. It is possible to argue that CRISPR is not as high risk as nuclear material, but it is equally possible to counter-argue (as some have) that risk is impossible to predict for ecosystem-altering technologies whose effects-and therefore risks-do not scale linearly (Heinemann et al. 2021). Access has also been discussed in terms of legibility of genetic data and broadband access for many rural regions of the US and Global South. Both arguments have merit yet do not go far enough. The ability to download sequence data and interpret genetic code is just the razor edge of a massive $\mathrm{R} \& \mathrm{D}$ endeavor. Few garage DIY innovators or smallholder villages have access to the resources - the labs, the transformation facilities, the armies of postdocs and research assistants, the government grantsto turn an experiment into a crop of any social value.

Access as a matter of distributional equity also pertains to seed and biotech companies. Developers and entrepreneurs suggest that CRISPR will democratize gene editing by lowering the barriers to entry for small and medium scale enterprises, helping curb monopolistic market control by agrochemical giants like Monsanto/Bayer (Taylor 2019). These arguments are based not only on CRISPR's cheapness relative to earlier generations of GM technologies but on prospects that gene editing could be deregulated by governments. For example, in 2019, the chair of the European Parliament's agriculture committee argued that it is relatively easy for larger companies to comply with the EU's GMO regulations, but smaller ones are badly affected by the ruling of the European Court of Justice that gene-edited crops and foods fall under the EU's GMO regulation and thus must be safety-checked and labeled (Foote 2019).

Claims that gene editing favors the market underdogs are not without merit. Partly due to CRISPR's relative affordability, the technology has been widely adopted by start-up companies such as Inari, Pairwise, Benson Hill Biosciences, and Yield 10. However, the political economy of innovation is more complex than democratization narratives imply. An analysis by TestBiotech, a German institute for independent technology assessment, found that Corteva Agriscience (previously DowDuPont) controls large parts of the seed market through an effective patent cartel on CRISPR. The company has signed exclusive or non-exclusive contracts with all owners of the foundational patents on CRISPR/Cas technology (Contreras and Sherkow 2017; Broad 2017). ${ }^{4}$

\footnotetext{
4 There are two principal licensing groups-those of the University of California and the MIT/Harvard Institute. The Broad group includes Harvard, MIT, Duke University, and Beam Therapeutics, as
} 
In addition, notes TestBiotech (2019): "Data presented in a meeting with the EU Commission at the end of 2018 show that DowDuPont has successfully managed to combine 48 patents on the most basic tools in one patent pool. According to DowDupont, access to such a high number of patents is necessary in order to apply the technology in plant breeding to its full extent."

For small seed companies, it's not just patents but licensing agreements that mediate access. Licenses grant formal permission to use gene-editing technologies and come in a kaleidoscopic variety. Most relevant to start-ups are three categories: evaluation, research, and commercial. Evaluation licenses are granted to researchers by the owners of technology to do basic and preliminary research; these types are typically low cost and help developers learn if they want to pursue an application. If so, the IP owner can grant research licenses. In turn, commercial licenses are pursued when moving from labs into markets. Here, costs quickly escalate, with large companies requiring hefty payments in the form of commercial licensing fees, royalty payments on product sales, or fees for use of the technology (Robinson 2019). This commercial licensing landscape is currently configured to enable Corteva and other companies to pool patents and demand licensing contracts in ways that secure a dominant market position.

Small and medium-scale firms, in other words, struggle to afford the patents and commercial licensing agreements that govern gene editing. This is their access obstacle, more so than costs of GM regulation-which the firm Phillips McDougall (2011) estimates at roughly $26 \%$ of total research and development costs for a trait. As importantly, "small" is often never intended as an alternative to large. In a world of biotech startups characterized by extreme turnover, venture capital, and racing to design the next disruptive innovation, many smaller firms will eventually partner with or be taken over by larger companies whose efficiencies of scale cannot be matched. Lucrative buyouts, for many small firms, are the desired outcome (Glasner 2018). Universities also stand to gain from supporting the private sector, which is why they have offices of technology transfer whose sole interest is to transfer "inventions" generated by their academic staff to industry (Kloppenburg 2004; Glenna et al. 2007).

To get beyond an oversimplified access frame, then, requires that agroecologists and gene editors grapple more openly and honestly with the political economy of innovation in which CRISPR is embedded. It also requires profound reconfiguration of economic policy to contain the fallout

\section{Footnote 4 (continued)}

well as the Broad Institute. The UC group includes the University of Vienna, Emannuelle Charpentier, and University of California (Contreras and Sherkow 2017). that putting farmers onto technological treadmills otherwise brings. For example, in the US context, a repeal of the landmark Bayh-Dole Act (see: Zaitchik 2021) could begin to limit intellectual property on publicly funded science that now glides into proprietary hands via licensing agreements. In terms of economic policy, a nationwide return to parity pricing and supply management could reshape production incentives to reduce the problem of structural surplus and, thus, ever cheaper prices and escalating debt for farmers (Carlisle and Montenegro de Wit et al. 2019; Disparity to Parity 2021). These types of efforts mark the extent to which complementarity is less about reconciling technologies than about transforming social structures and the food systems they support. Changing everything is certainly possible. But transformation isn't something agroecologists and gene editors will do, or want to, if the actions and their implications don't cohere with the worldview within which change is imagined and made possible.

\section{Ontologies: inside or outside the house of modernity?}

'Sovereignty is only as good as the values you place in it.'

- Joanne Barker, Lenape feminist, quoted by Melanie Yazzie (2021)

Above I have argued that agroecology and gene editing represent distinctive ways of knowing about the world, giving rise to particular, often orthogonal, assessments of what the underlying problems are and how social change occurs. But epistemology in the modern world is too often separated from ontology, with thanks to Descartes for etching the binary. To borrow from Stein (2019) who borrows from Shotwell (2016, p. 38), my arguments work from the premise that "[w]e don't just have a knowledge problem-we have a habit-of-being problem."

The ontological divide between gene editors and agroecologists is helpfully glimpsed through the lens of coloniality/modernity, where it's possible to map specific architectures of worldmaking and existence. Many people have laid the groundwork for thick descriptions of modernitycoloniality and the ongoing coloniality/decoloniality struggle (eg. Fanon 1963 [2004]; Quijano 2007; Tuhiwai Smith 2012; Mignolo and Escobar 2013). A simplifying metaphor is offered by Stein et al. (2017) who describe the "house that modernity built." This house sits on a foundation of separability, an ideological base which enables domination through the production of ontological categories (such as "subject" v. "object", "human" v. "nature") and modes of valuation and measurement that divide, subordinate, and create the hierarchical world as we know it. Atop the foundation of 
separability, the structure of the house consists of two loadbearing walls. One is Enlightenment humanism ensconcing principles of universal reason in the house. The other is the nation-state, which according to modernity's realtors, is a fantastic feature: humans can freely and rationally decide to cede certain freedoms for the promise that the state will secure and protect life, liberty, and property. These two walls hold up the "roof" of global capital, which keeps resources flowing to and from the house, and makes the living quarters more comfortable.

The house, however, is both toxic and precarious. Moreover, the precarity doesn't stem from foreign forces, an idea that serves to rationalize racist and xenophobic law-andorder responses by the security state. Rather, modernity is threatened by what it takes to sustain the house itself: violent dispossession of communities' land, water, and seeds; exploitation of underpaid workers in the house's "basement" and beyond its walls; psychological oppression via prejudice and self-negation, which colonized peoples throughout the world have long internalized (Fanon 1952 [2008]). "All of these activities that built and keep the house running," note Stein et al. (2017, p. 73), "have long been poisonous to those outside of it or in the unmaintained parts of its own interior, but now those poisons are starting to seep back into the walls and foundations of the house and its main floors, leading to a variety of different responses." What do these responses look like? For Stein, Andreotti, and colleagues, a key reference point is denial of coloniality-modernity's existence and implications. Denials can be analytically distinguished and include: (1) complete denial that problems exist; (2) soft, "interpretive denial" of coloniality-modernity's problems; (3) acceptance of critique but denial of full implications; (4) "no denial" of coloniality-modernity (see also Andreotti 2020).

In conversation with these 4 denials, I suggest that technologies like CRISPR draw into sharp relief where gene editors and agroecologists stand within the organizing ontology of coloniality-modernity. Some biotechnologists may be in full-blown denial of the violent, extractive, dispossessive, and ecocidal processes upon which the house of modernity rests. Most, however, don't appear blind to the problems this housing project produces-they only have a selective interpretation of its harm. From the perspective of many a gene editor, the house is unsustainable due to inefficiency and wastefulness. People in the house experience food insecurity and hunger because of production scarcity, lack of education, and unoptimized resource use. Violence does exist, yes, but it stems from long-term lack of access to beneficial technologies, data and information infrastructures, and supportive policy and market institutions. The solutions, then, are obvious: enhance inclusion and access by filling "knowledge gaps" and by extending markets, trade, and technologies to underserved communities.
Such denialism was palpable, for example, in a Nature opinion published in August 2021 by members of the UN Food Systems Summit's Scientific Group. Summarizing "7 priorities to end hunger and protect the planet," the authors argued that "Genetic engineering and biotechnology should be applied to increase the productivity, quality and resistance of crops to pests and drought.... To widen access to bioscience technologies, intellectual-property rights, skills and data sharing should be addressed" (von Braun et al. 2021, p. 29). This perspective appears logical and coherent within the framework of coloniality-modernity where the costs of unsustainable growth are externalized and where violence to bodies, workers, and land subsidizes the price of doing business. It's also perfectly sensible that CRISPR would serve well to maintain a house where universally-relevant rationality is a load-bearing wall. With ostensibly greater precision, certainty, and predictability relative to older biotech methods, CRISPR offers nothing less than promissory control over the forms nature and people can take, helping shore up the house's structural integrity.

By contrast, agroecologists tend to fall into both "denial of full implications" and "no denial" camps. In the former, the core problem of unsustainability is structural as opposed to technical. Solutions lie in addressing power relations and social obligations to one another and the planet. Since ecological degradation, food insecurity, and hunger are products of poor governance and corporate greed, their resolution lies in connecting scientists to social movements, nurturing public action and pressuring governments to support policies for agroecology and food sovereignty (eg. IPES-Food 2016, 2017). Colonial violence should be addressed through systemic changes, including through redistributing resources and centering marginalized communities of Indigenous, Black, and brown farmers, food workers, and migrant and migratory labor.

For the "no denial" camp, which we might also call radical-Indigenous ${ }^{5}$ (see: Holt-Giménez and Shattuck 2011; Ajl 2021; The Red Nation 2021), ecological unsustainability and food crises are different manifestations of the same nexus: racial capitalism, imperialism, colonialism, and the world ecology they cocreate. So while certain fixes might be helpful, including policies and technologies, we will ultimately need to surrender this way of being/living in the world and enact another mode of existence. While the partial denialists recognize power relations and are committed to designing collective structures that transcend individual choice, the no denialists go further: relationality and responsibility

\footnotetext{
5 radical is often understood as "extreme." Here I emphasize the etymological origins in radicalis, meaning "root." To borrow from Angela Davis (2006), "Radical simply means 'grasping things at the root.".
} 
operate at many entangled layers and levels, including a nonAnthropocentric existential layer and a political layer that rejects systemic violence. Both work short-term, to care for vulnerable people and ecologies, and long term, to abolish violent institutions and mobilize the collective work of nourishing and wellbeing.

The decentering of humans is particularly strong among Indigenous non-denialists, for whom the ontology of modernity is blind to most of the living world. Speaking to Suárez-Torres et al. (2017, p. 246), Enrique Cachiguango, an Indigenous intellectual in Ecuador, explained: "One of the most important philosophical principles is that the world is a living thinking being (self-conscious), with feelings and knowledge. The atom of matter, the water molecule, animal and plant cells are all alive and intelligent. That is why in the vocabulary of indigenous languages everything is considered a living being."

For Cachiguango, as for many Kichwa (or Quechua) people of the Andes, including my ancestors, the concept of the Pacha Mama reflects how the "Mother Earth" embodies and organizes all beings. A relationship etched in coevolutionary time connects organisms to one another and has produced the ayllu, which, as a political, economic, and administrative system and cultural landscape continues to be nurtured by Andean peoples. The main objective of the ayllu is neither accumulation nor "development." Rather, it's wellbeing (Sumaq Qausay) defined as good relations between human beings and their social and natural environments. "It means to be in equilibrium with one's natural and social surroundings and to maintain reciprocity between all beings, including Pacha Mama" (Argumedo and Wong 2010, p. 85). The Andean cosmology is only one example of the non-denialist ontology; worldwide and across Turtle Island, communities have expressed, and continue to nurture and live within, worlds outside the house modernity built.

These ontological differences between gene editors and agroecologists are far from monolithic, smooth, or static. For example, communities and people (myself included) can move between these worlds over a lifetime and even, "code switching," in the course of a working day. The varying modes of denial do, however, serve to illustrate the profundity of the complementarity question. The ask is nothing less than the question of development (e.g., development as achieving modernity vs. development as uneven processes central to capitalist expansion vs. development as colonial violence); the objective of sustainability (to achieve "development" vs sustaining reciprocal wellbeing); and entanglement (to untangle for order and control vs. to entangle stochastic relations in and with the living world).

CRISPR developers are, to some extent, recognizing these ontological gaps, judging by efforts to invite Indigenous peoples and smallholders to conferences such as CRISPRcon-an annual summit aimed at convening "a broad selection of diverse voices...to discuss the future of CRISPR and related gene editing technologies" (CRISPRcon 2021). These discussions are not without merit, and agroecologists who abstain risk sidelining the agroecological position altogether. At the same time, what gene editors often fail to recognize is that engaging with differing ontological communities is not just about content-inviting divergent views into the room-it is about process and power therein. This includes understanding the difference between an invitation by elites to the decision-making table and a co-created space for deciding if and how a table might be built. It includes dialogue at the earliest possible stage to map spaces of divergence, convergence, and principles of moving, or pausing, based on negotiated agreements. It includes attentiveness to preexisting privilege and asymmetries of power whenever communities inside, outside, and on different floors of the "house of modernity" mix.

Studies of participatory technology assessments of GM crops have broken important ground in this regard (eg, Tavella 2016). In such assessments, "extended peer communities" deliberate the benefits and risks of access, recognizing the diversity of legitimate perspectives to construct and validate knowledge on every issue (Ravetz 2006). This approach breaks from top-down technology transfer models, putting agency more assuredly in the hands of directly affected communities. However, even participatory technology assessments generally imply that farmers are merely receiving or rejecting technologies designed by others, rather than shaping the contours of technologies themselves. What would technologies produced by, for, and alongside agroecological farmers and communities look like? Can those who work the land regain power to determine whether, on those terms, and what kinds of technologies are born? Might technology governance pivot from post-hoc invitations and technology consultancies to autonomous organization of technological projects? These questions begin with centering communities that the house of modernity abuses and yet fundamentally depends upon. They crack open the prospect of technology sovereignty.

\section{Towards technology sovereignty?}

"Agroecology," Altieri and Toledo have argued (2011, p. 607), "provides the principles for rural communities to reach food sovereignty but also energy and technological sovereignty within a context of resiliency." But while food sovereignty has been extensively studied, debated, and reworked, technology sovereignty remains grossly underdeveloped. This paper does not claim to fill that gap, but I propose a starting point for further dialogue and elaboration. Building on the pillars of food sovereignty codified by rural social movements in Nyèlèni, Mali, in 2007 and summarized in 6 
Table 1 Six principles for technology sovereignty

Food Sovereignty (USFSA, n.d.)

\section{Focuses on food for people}

Food sovereignty puts the right to sufficient, healthy and culturally appropriate food for all at the center of food, agriculture, livestock and fisheries policies

\section{Values food providers}

Food sovereignty values all those who grow, harvest and process food, including women, family farmers, herders, fisherpeople, forest dwellers, indigenous peoples, and agricultural, migrant and fisheries workers

\section{Localizes food systems}

Food sovereignty brings food providers and consumers closer together so they can make joint decisions on food issues that benefit and protect all

\section{Puts control locally}

Food sovereignty respects the right of food providers to have control over their land, seeds and water and rejects the privatization of natural resources

\section{Builds knowledge and skills}

Food sovereignty values the sharing of local knowledge and skills that have been passed down over generations for sustainable food production free from technologies that undermine health and well-being

\section{Works with nature}

Food sovereignty focuses on production and harvesting methods that maximize the contribution of ecosystems, avoid costly and toxic inputs and improve the resiliency of local food systems in the face of climate change
Technology Sovereignty

\section{Focuses on technology for people}

Technology sovereignty puts the right to appropriate technologies for all at the center of food and agriculture, science, and technology policies. Appropriate includes sensitivity to scale, to culture and geography, and to gender, class, race, dis/ability, and other axes of current inequity

\section{Values food providers as tech providers}

Technology sovereignty values all those who grow, harvest and process food as agents of making, using, and governing technology. These makers and decision-makers include women, family farmers, herders, fisherpeople, forest dwellers, Indigenous peoples, and agricultural, migrant, and fisheries workers

\section{Localizes tech systems}

Technology sovereignty brings technology providers and users closer together so they can make joint decisions on technological issues. In food systems, people should express agency as both makers and users of technology, and decisions should support sovereign food systems via technological and other means

\section{Puts control locally}

Technology sovereignty respects the right of communities to have control over tools, techniques, data, and digital and material infrastructures. It rejects the privatization of knowledge and natural resources, and it supports alternatives to intellectual property rights over technologies and their products

\section{Builds knowledge and skills}

Technology sovereignty values and seeks consent-based sharing of Indigenous, local, and other land-based knowledge, skills, and technologies that have been passed down over generations for sustainable food production without reliance on technologies (and related inputs and property rights) that undermine health and well-being

\section{Works with nature}

Technology sovereignty focuses on innovation methods that maximize the contribution of ecosystems, avoid costly and toxic inputs, and improve the resiliency of territorial and trans-local food systems in the face of climate change. Technology that works with nature will enhance agrobiodiversity and supportive ecosystemic processes, not diminish them key themes by the US Food Sovereignty Alliance, I offer 6 principles for technology sovereignty centered on agriculture and food (Table 1).

Putting these principles into practice with CRISPR, technology sovereignty would include the right of farmers (as food providers) to be tech providers to the extent they are willing and able. It would recognize that organic farmers in the Salinas Valley who already work 18 -h days might not have the interest or means to join biohacker labs, even those dedicated to "appropriate" technologies. But it would also recognize that interest and means are partly conditioned by the situation that exists now, as opposed to a desired situation in which farmer-led innovation is robustly supported. What might such conditions look like? The principle of "local control" suggests that funding and resources could come from a range of public sources, but local innovation would rest upon the sovereign rights of communities to have control over gene editing tools, data, products, and platforms. Further, because communities vary widely in their cultures, geographies, histories, power and privilege, the principle of technology "for the people" avoids universalizing terms and suggests instead the right to scale-appropriate, non-proprietary, and culturally relevant CRISPR technology.

As with food sovereignty, the contradictions embedded in such claims are noteworthy. Phrases like "technological sovereignty....for all" spans providers and consumers of technology, including the corporate actors to which technology sovereignty supposedly poses an alternative. Yet as with food sovereignty, one way to smooth these wrinkles is through the explicit introduction of rights-based language. "To talk of a right to shape food policy is to contrast it with a privilege" (Patel 2009, p. 667). In the same way, to talk of a right to shape technological policy is to contrast it with the privilege to do so. Since the modern technological system 
has been built by, and remains the playground for, a handful of privileged tech giants, technology sovereignty offers a powerful discursive claim. It insists that such hegemony is illegitimate because the design of our social system (technology included) is not the privilege of a few, but the right of all.

The right of all, in gene editing, would include the right for farmers to deliberate on what kinds of agronomic problems a CRISPR'd organism would feasibly address, which trait or sets of traits might be involved (eg. the implications of an herbicide tolerant grain being different from those of a sturdier garden vegetable), and how those new seeds or animals or insects would affect their local conditions. It would include the rights of communities, rural and urban, to evaluate the extent to which technology "works with nature" and "values food providers as tech providers" including system-wide effects on agrobiodiversity, household gender and labor relations, land ownership and land loss, and ecosystem resilience short- and long-term. Women's education, in this vein, becomes a powerful agroecological technology.

Finally, technology sovereignty is about "building knowledge and skills," and should include the right to engage relevant experts in a critical, historical accounting of where specific agricultural problems originate and why. It should foreground the right to appraise a wide range of solutions based on this "root cause" understanding - and to have more options on the table than either new biotechnologies or the industrial status quo. When and if new technologies go forward, tech sovereignty means ensuring that Indigenous and local knowledge is neither delegitimated nor materially sidelined by new innovations, but rather should be advanced by and reflected in them. The principles for technology sovereignty I have suggested could set the floor (not the ceiling) for bottom-up and participatory technology assessments, such as the l'ECID-Espace Citoyen d'Interpellation Démocratique (Citizen's Space for Democratic Deliberation)—which took place in Mali in 2006. Over roughly 15 months, and modeled on the cyclic reflection-action process of participatory action research, l'ECID brought together 45 female and male farmers representing every district in the Sikasso region, specialist witnesses from various continents, a panel of independent observers, and members of the national and international media. More than a chance to debate the pros and cons of GM cotton for Mali, it became a space for a "balanced and trustworthy deliberative process" enabled by the unique combination of Western citizen's juries with Indigenous methods for debate and dialogue, including the traditional African palaver (Pimbert and Barry 2021).

In other words, for CRISPR to be "complementary" with agroecology requires a recognition that agroecology isn't reducible to polyculture or pest management. Agroecology is, at base, a process for achieving food sovereignty and technology sovereignty. It is the process for establishing collectively negotiated community agreements and accountability standards through which sovereignty is forged. Will gene editors and other tech developers be open to these terms of engagement? It may depend on the extent to which the dominant ontological order can be understood, subverted, and transformed.

\section{Conclusion}

In this paper, I have asked a seemingly simple question: can gene editing be compatible with agroecology? The question is hardly rhetorical, as can be seen with the controversial UN Food Systems Summit (UNFSS) and counter-mobilizations against the summit, where technological visions and agroecological visions battled for authority and epistemic legitimacy (Ackermann et al. 2021; Jonas 2021; Montenegro de Wit and Iles 2021). For Summit organizers and backers, notably the World Economic Forum and the Gates Foundation, complementarity offers a way to both capitalize on agroecology's momentum and to neutralize it by deflecting agroecological demands that global elites avoid at all costs: land reparations and land redistribution, wealth deconcentration and economic justice, rematriations of Native and peasant seeds. The UNFSS, moreover, sought to unseat the multilateral governance framework of the UN Committee on Food Security (Canfield et al. 2021; Clapp et al. 2021) whose High Level Panel of Experts has questioned the appropriateness of biotechnology for agroecological futures (HLPE 2019). In this charged political context, with tech elites actively discrediting and bypassing institutions that support agroecology's legitimacy, agroecologists who hold out hope for technology will rightly question the strategic wisdom of vocalizing that hope. Yet, this paper has argued, CRISPR can be complementary to agroecology, assuming that transformations of monopoly power, racial capitalist violence, and ongoing colonial rule can occur.

To make that argument, I have worked through 9 layers of the complementary question. Exploring knowledge foundations, "win-win" mythologies, and root-cause problems, I argued that calls for CRISPR/agroecology compatibility have almost always focused on technical aspects (eg. growing gene edited crops in polyculture fields) because looking at epistemic and structural compatibility would reveal lockouts and win-losses that techniques alone cannot destabilize or fix. I shed light on distinct assumptions about nature etched into the saving-land-from-people discourse of gene editors versus the saving-land-with-people discourse of agroecology. Those discursive struggles also revealed why agroecologists are seldom the ones broaching the conversation about complementarity. Frequently framed as ignorant about, or "anti" technology, agroecologists' position is 
informed by the evidence on hand: where race-class inequality is propagated, invisibilized, and normalized by seemingly neutral information architectures; where technological access has never smoothly translated into social wellbeing; where agrarian history is littered with benefits that are uneven, that constitutively produce harm amidst gain, and that collapse over time into livelihood and ecological crises.

To conclude, I argue that access should be reworked into technology sovereignty: a bolder challenge that rests on people's rights to make decisions about and co-create technologies that reflect, respond to, and mobilize communities' collective knowledge and power. Such sovereignty, I suggest, is possible and will ultimately make complementary viable, if indeed this is what smallholders and Indigenous communities, in all their locally specific diversities, want and choose. This will not require perfect harmonization of divergent epistemologies and ontologies, which is neither possible nor desirable. But it will demand a reckoning with the politics of technology and the worldmaking of coloniality that technology can either work to shore up or can help shatter.

Acknowledgements I am grateful to multiple research clusters with whom I've had the opportunity to engage in ongoing questions over gene editing and agroecology. These include, but are not limited, to: contributors to the Elementa Gene Editing the Food System special feature, the UC Innovative Genomics Institute, CRISPRcon, A Bigger Conversation, the Agroecology Research-Action Collective, and interlocutors with the Civil Society and Indigenous Peoples Mechanism. My sincerest appreciation for the anonymous AHUM reviewers for comments and suggestions that strengthened the result.

Funding This research was supported by University of California, Santa Cruz, startup funds and the UC President's Postdoctoral Fellowship research funds.

Availability of data and material Documentary materials are all available at references cited in the bibliography. No further datasets were generated for this research.

Code availability Not applicable.

\section{Declarations}

Conflict of interest The author declares no conflict of interest.

Open Access This article is licensed under a Creative Commons Attribution 4.0 International License, which permits use, sharing, adaptation, distribution and reproduction in any medium or format, as long as you give appropriate credit to the original author(s) and the source, provide a link to the Creative Commons licence, and indicate if changes were made. The images or other third party material in this article are included in the article's Creative Commons licence, unless indicated otherwise in a credit line to the material. If material is not included in the article's Creative Commons licence and your intended use is not permitted by statutory regulation or exceeds the permitted use, you will need to obtain permission directly from the copyright holder. To view a copy of this licence, visit http://creativecommons.org/licenses/by/4.0/.

\section{References}

Ackermann, M., S. Vicente, and S. Monsalve. 2021. The Latin American and Caribbean counter-mobilization against the UN Food Systems Summit: Magdalena Ackermann in conversation with Saúl Vicente and Sofía Monsalve. Development. October 27. https://doi.org/10.1057/s41301-021-00324-x.

Aga, A. 2021. Farm protests in India are writing the green revolution's obituary. Scientific American. https://www.scientific american.com/article/farm-protests-in-india-are-writing-thegreen-revolutions-obituary/. Accessed 7 June 2021.

AGRA (Alliance for the Green Revolution in Africa). 2021. Our strategy-AGRA. https://agra.org/our-strategy/. Accessed 5 Sept 2021.

Agroecology Europe. 2021. AEEU Webinar on "Technological innovations for the agroecological transition." Agroecology Europe, May 27.

Aj1, M. 2021. A people's green new deal. London: Pluto Press.

Alger, J. 2008. A guide to global nuclear governance: Safety, security, and non-proliferation. The Centre for International Governance Innovation. https://www.cigionline.org/sites/default/ files/a_guide_to_nuclear_power.pdf. Accessed 7 June 2021.

Altieri, M.A. 1995. Agroecology: The science of sustainable agriculture, 2nd ed. London: Westview Press.

Altieri, M.A., and L. Merrick. 1987. In situ conservation of crop genetic resources through maintenance of traditional farming systems. Economic Botany 41 (1): 86-96. https://doi.org/10. 1007/BF02859354

Altieri, M.A., C. Nicholls, and R. Montalba. 2017. Technological approaches to sustainable agriculture at a crossroads: An agroecological perspective. Sustainability 9 (3): 349. https://doi. org/10.3390/su9030349.

Altieri, M.A., and V.M. Toledo. 2011. The agroecological revolution in Latin America: Rescuing nature, ensuring food sovereignty and empowering peasants. Journal of Peasant Studies 38 (3): 587-612. https://doi.org/10.1080/03066150.2011.582947.

Anderson, C.R., and M. Pimbert. 2018. The battle for the future of farming: what you need to know. The Conversation, November 21. http://theconversation.com/the-battle-for-the-futureof-farming-what-you-need-to-know-106805. Accessed 6 June 2021.

Andreotti, V. 2020. Gesturing Towards Decolonial Futures: lecture: "The house of modernity." September 1. https://bit.ly/3k3Ig Uv. Accessed 5 Sept 2021.

Argumedo, A., and B. Yun Loong Wong. 2010. The ayllu system of the Potato Park (Peru). In Sustainable use of biological diversity in socio-ecological production landscapes. Background to the 'Satoyama Initiative for the benefit of biodiversity and human well-being.,' ed. C. Bélair, K. Ichikawa, B. Y. L. Wong, and K. J. Mulongoy, 184 pages. Secretariat of the Convention on Biological Diversity. Technical Series No. 522. Montreal.

Badgley, C., J. Moghtader, E. Quintero, E. Zakem, M.J. Chappell, K. Avilés-Vázquez, A. Samulon, and I. Perfecto. 2007. Organic agriculture and the global food supply. Renewable Agriculture and Food Systems 22 (2): 86-108. https://doi.org/10.1017/ S1742170507001640.

Belay, M., and B. Mugambe. 2021. Bill Gates Should Stop Telling Africans What Kind of Agriculture Africans Need. Scientific American, July 6. https://www.scientificamerican.com/artic le/bill-gates-should-stop-telling-africans-what-kind-of-agric ulture-africans-need1/. Accessed 5 September 2021.

Benjamin, R. 2019. Race after technology: Abolitionist tools for the new Jim code. Medford, MA: Polity.

Bennett, A.B., C. Chi-Ham, G. Barrows, S. Sexton, and D. Zilberman. 2013. Agricultural biotechnology: Economics, 
environment, ethics, and the future. Annual Review of Environment and Resources 38 (1): 249-279. https://doi.org/10. 1146/annurev-environ-050912-124612.

Bernard, B., and A. Lux. 2017. How to feed the world sustainably: An overview of the discourse on agroecology and sustainable intensification. Regional Environmental Change 17 (5): 1279 1290. https://doi.org/10.1007/s10113-016-1027-y.

Bezner Kerr, R. 2013. Seed struggles and food sovereignty in northern Malawi. Journal of Peasant Studies 40 (5): 867-897. https://doi.org/10.1080/03066150.2013.848428.

Boadi, R.Y., and M. Bokanga. 2007. The African Agricultural Technology Foundation approach to IP management. In Intellectual property management in health and agricultural innovation: $A$ handbook of best practices, ed. A. Krattinger, R. T. Mahoney, L. Nelson, and et al. Oxford, UK: MIHR and PIPRA: Davis.

Bollier, D., and S. Helfrich. 2019. Free, fair, and alive: The insurgent power of the commons. Gabriola Island, British Columbia: New Society Publishers.

Broad. 2017. DuPont Pioneer and Broad Institute join forces to enable democratic CRISPR licensing in agriculture. Broad Institute. October 18. https://www.broadinstitute.org/news/ dupont-pioneer-and-broad-institute-join-forces-enable-democ ratic-crispr-licensing-agriculture. Accessed 5 Sept 2021.

Buttel, F.H. 2005. Ever since Hightower: The politics of agricultural research activism in the molecular age. Agriculture and Human Values 22 (3): 275-283. https://doi.org/10.1007/ s10460-005-6043-3.

Canfield, M., M.D. Anderson, and P. McMichael. 2021. UN Food Systems Summit 2021: Dismantling democracy and resetting corporate control of food systems. Frontiers in Sustainable Food Systems 5 (April): 661552. https://doi.org/10.3389/fsufs. 2021.661552.

Carlisle, L., M. Montenegro de Wit, M.S. DeLonge, A. Iles, A. Calo, C. Getz, J. Ory, et al. 2019. Transitioning to sustainable agriculture requires growing and sustaining an ecologically skilled workforce. Frontiers in Sustainable Food Systems 3 (November): 96 . https://doi.org/10.3389/fsufs.2019.00096.

Carney, J.A. 2001. Black rice: The African origins of rice cultivation in the Americas. Cambridge, MA: Harvard University Press.

Carolan, M. 2020. Automated agrifood futures: Robotics, labor and the distributive politics of digital agriculture. The Journal of Peasant Studies 47 (1): 184-207. https://doi.org/10.1080/ 03066150.2019 .1584189 .

Chappell, M.J. 2018. Beginning to end hunger: Food and the environment in Belo Horizonte, Brazil, and beyond. Oakland, CA: University of California Press.

Chappell, M.J., and L.A. LaValle. 2011. Food security and biodiversity: Can we have both? An agroecological analysis. Agriculture and Human Values 28 (1): 3-26. https://doi.org/10.1007/ s10460-009-9251-4.

Clapp, J., M.D. Anderson, M. Rahmanian, and S. Monsalve Suárez. 2021. An "IPCC for food?" How the UN Food Systems Summit is being used to advance a problematic new science-policy agenda. IPES-Food briefing note on the governance of food systems, July. http://www.ipes-food.org/_img/upload/files/ GovBrief.pdf. Accessed 5 Sept 2021.

Clément, C., and F. Ajena. 2021. Paths of least resilience: Advancing a methodology to assess the sustainability of food system innovations - the case of CRISPR. Agroecology and Sustainable Food Systems 45 (5): 637-653. https://doi.org/10.1080/ 21683565.2021.1890307.

Cohen, J. 2019. China's CRISPR revolution. Science 365 (6452): 420-421. https://doi.org/10.1126/science.365.6452.420.

Collins, E. D., and K. Chandrasekaran. A wolf in sheep's clothing? An analysis of the 'sustainable intensification' of agriculture. Amsterdam, NL: Friends of the Earth International. https://
www.foei.org/wp-content/uploads/2013/12/Wolf-in-SheepsClothing-for-web.pdf. Accessed 28 Oct 2021.

Contreras, J.L., and J.S. Sherkow. 2017. CRISPR, surrogate licensing, and scientific discovery. Science 355 (6326): 698-700. https://doi.org/10.1126/science.aal4222.

CRISPRcon. 2021. CRISPRcon-Conversations on science, society and the future of gene editing. CRISPRcon. https://crisprcon. org/. Accessed 7 June 2021.

Cullather, N. 2010. The hungry world: America's Cold War battle against poverty in Asia. Cambridge, MA: Harvard University Press.

Curtis, T.Y., S.J. Powers, R. Wang, and N.G. Halford. 2018. Effects of variety, year of cultivation and sulphur supply on the accumulation of free asparagine in the grain of commercial wheat varieties. Food Chemistry 239 (January): 304-313. https://doi. org/10.1016/j.foodchem.2017.06.113.

Curtis, T.Y., S. Raffan, Y. Wan, R. King, A. Gonzalez-Uriarte, and N.G. Halford. 2019. Contrasting gene expression patterns in grain of high and low asparagine wheat genotypes in response to sulphur supply. BMC Genomics 20 (1): 628. https://doi.org/ 10.1186/s12864-019-5991-8.

Da Silva, D.F. 2014. Toward a Black feminist poethics: The quest(ion) of Blackness toward the end of the world. The Black Scholar 44 (2): 81-97. https://doi.org/10.1080/00064246.2014. 11413690.

Davis, A. 2006. Angela Davis Lecture Moe Lectureship in Women's Studies, Gustavus Adolphus College, St. Peter, Minnesota. April 12.

David, S., and L. Sperling. 1999. Improving technology delivery mechanisms: Lessons from bean seed systems research in eastern and central Africa. Agriculture and Human Values 16 (4): 381-388. https://doi.org/10.1023/A:1007603902380.

de la Cadena, M. 2015. Earth beings: Ecologies of practice across Andean worlds. Durham: Duke University Press.

de Sousa Santos, B. 2014. Epistemologies of the South: Justice against epistemicide. Boulder, CO: Paradigm.

Disparity to Parity. 2021. Disparity to Parity: A call to mandate fair pricing and update supply management to build a racially just, economically empowered, and climate resilient food system. https://disparitytoparity.org/. Accessed 5 Sept 2021.

Doudna, J.A., and E. Charpentier. 2014. The new frontier of genome engineering with CRISPR-Cas9. Science 346 (6213): 12580960 12580969. https://doi.org/10.1126/science.1258096.

Dunbar-Ortiz, R. 2014. An indigenous peoples' history of the United States. New York: Beacon Press.

Eddens, A. 2019. White science and indigenous maize: The racial logics of the green revolution. The Journal of Peasant Studies 46 (3): 653-673. https://doi.org/10.1080/03066150.2017.1395857.

Egelie, K.J., G.D. Graff, S.P. Strand, and B. Johansen. 2016. The emerging patent landscape of CRISPR-Cas gene editing technology. Nature Biotechnology 34 (10): 1025-1031. https://doi. org/10.1038/nbt.3692.

Eubanks, V. 2017. Automating inequality: How high-tech tools profile, police, and punish the poor. New York: St. Martin's Press.

Fanon, F. 1952. Black skin, white masks. New York: Grove Press.

Fanon, F. 1963 [2004]. The wretched of the earth. New York: Grove Press.

FAO, IFAD, UNICEF, WFP, and WHO. 2020. The state of food security and nutrition in the world 2020. Transforming food systems for affordable healthy diets. Rome: FAO: FAO, IFAD, UNICEF, WFP and WHO. https://doi.org/10.4060/ca9692en.

Figueroa-Helland, L., C. Thomas, and A. Pérez Aguilera. 2018. Decolonizing food systems: Food sovereignty, indigenous revitalization, and agroecology as counter-hegemonic movements. Perspectives on Global Development and Technology 17 (1-2): 173-201. https://doi.org/10.1163/15691497-12341473. 
Fischer, J., B. Brosi, G.C. Daily, P.R. Ehrlich, R. Goldman, J. Goldstein, D.B. Lindenmayer, et al. 2008. Should agricultural policies encourage land sparing or wildlife-friendly farming? Frontiers in Ecology and the Environment 6 (7): 380-385. https://doi.org/ $10.1890 / 070019$

Fister, A.S., L. Landherr, S.N. Maximova, and M.J. Guiltinan. 2018. Transient expression of CRISPR/Cas9 machinery targeting TcNPR3 enhances defense response in Theobroma cacao. Frontiers in Plant Science 9 (March): 1-15. https://doi.org/ 10.3389/fpls.2018.00268.

Fleming, A., E. Jakku, L. Lim-Camacho, B. Taylor, and P. Thorburn. 2018. Is big data for big farming or for everyone? Perceptions in the Australian grains industry. Agronomy for Sustainable Development 38 (3): 24. https://doi.org/10.1007/ s13593-018-0501-y.

Foote, N. 2019. MEPs slam gene-editing court ruling as damaging for SMEs. Euractive. https://www.euractiv.com/section/agriculturefood/news/meps-slam-gene-editing-court-ruling-as-damagingfor-smes/. Accessed 5 Sept 2021.

Francis, C., G. Lieblein, S. Gliessman, T.A. Breland, N. Creamer, R. Harwood, L. Salomonsson, et al. 2003. Agroecology: The ecology of food systems. Journal of Sustainable Agriculture 22 (3): 99-118. https://doi.org/10.1300/J064v22n03_10.

Garnett, T., M.C. Appleby, A. Balmford, I.J. Bateman, T.G. Benton, P. Bloomer, B. Burlingame, et al. 2013. Sustainable intensification in agriculture: Premises and policies. Science 341 (July): 33-34. https://doi.org/10.1126/science.1234485.

Gates, B. 2015. Can GMOs end world hunger by 2030? The Verge. February 18. https://www.theverge.com/2015/2/18/8061437/ bill-gates-can-gmos-end-world-hunger-by-2030. Accessed 5 Sept 2021.

Giraldo, O.F. 2018. Ecología política de la agricultura: agroecología y posdesarrollo. Primera edición. San Cristóbal de Las Casas, Chiapas: ECOSUR.

Glasner, J. 2018. Home run exits happen stealthily for biotech. TechCrunch. July 28. https://social.techcrunch.com/2018/07/28/ home-run-exits-happen-stealthily-for-biotech/. Accessed 6 Sept 2021.

Glenna, L.L., W.B. Lacy, R. Welsh, and D. Biscotti. 2007. University administrators, agricultural biotechnology, and academic capitalism: Defining the public good to promote university-industry relationships. The Sociological Quarterly 48 (1): 141-163. https://doi.org/10.1111/j.1533-8525.2007.00074.x.

Gliessman, S.R. 2013. Agroecology: Growing the roots of resistance. Agroecology and Sustainable Food Systems 37 (1): 19-31. https://doi.org/10.1080/10440046.2012.736927.

Gliessman, S.R. 2020. Transforming food and agriculture systems with agroecology. Agriculture and Human Values 37 (3): 547-548. https://doi.org/10.1007/s10460-020-10058-0.

Gomez, M.A., Z.D. Lin, T. Moll, R.D. Chauhan, L. Hayden, K. Renninger, G. Beyene, et al. 2019. Simultaneous CRISPR/Cas9mediated editing of cassava eIF4E isoforms $n C B P-1$ and $n C B P$ 2 reduces cassava brown streak disease symptom severity and incidence. Plant Biotechnology Journal 17 (2): 421-434. https:// doi.org/10.1111/pbi.12987.

González de Molina, M., P. Petersen, F.G. Peña, and F.R. Caporal. 2020. Political agroecology: Advancing the transition to sustainable food systems. Advances in Agroecology. Boca Raton, FL: CRC Press.

GRAIN. 2021. Infographic I Digital fences: Technology and its use in land grabbing. https://grain.org/en/article/6653-infographic-digit al-fences-technology-and-its-use-in-land-grabbing. Accessed 5 Sept 2021.

GRAIN and AFSA (African Food Sovereignty Alliance). 2019. The real seeds producers: Small-scale farmers save, use, share and enhance the seed diversity of the crops that feed Africa. October
29. https://grain.org/en/article/6035-the-real-seeds-producerssmall-scale-farmers-save-use-share-and-enhance-the-seed-diver sity-of-the-crops-that-feed-africa. Accessed 5 Sept 2021.

Greenberg, A. 2018. DIY guns: A landmark ruling opens the door for homemade firearms. Wired. July 10. https://www.wired.com/ story/a-landmark-legal-shift-opens-pandoras-box-for-diy-guns/. Accessed 6 Sept 2021.

Harding, S. 2007. Feminist standpoints. Handbook of feminist research: Theory and praxis: 45-69.

Harvey, D. 2007. A brief history of neoliberalism. Oxford: Oxford University Press.

Hecht, S. 2010. The new rurality: Globalization, peasants and the paradoxes of landscapes. Land Use Policy 27 (2): 161-169. https:// doi.org/10.1016/j.landusepol.2009.08.010.

Heinemann, J.A., D.J. Paull, S. Walker, and B. Kurenbach. 2021. Differentiated impacts of human interventions on nature. Elementa: Science of the Anthropocene 9 (1): 00086. https://doi.org/10. 1525/elementa.2021.00086.

Hernández Xolocotzi, E. 1985. Xolocotzia: Obras de Efraím Hernández Xolocotzi. Tomo 1. Revista de Geografía Agrícola. In In Universidad Autónoma de Chapingo, Texcoco: México. México.

HLPE (High Level Panel of Experts). 2019. Agroecological approaches and other innovations for sustainable agriculture and food systems that enhance food security and nutrition. A report by the High Level Panel of Experts on Food Security and Nutrition of the Committee on World Food Security, Rome. http://www.fao. org/3/ca5602en/ca5602en.pdf. Accessed 5 Sept 2021.

Hodson, E., U. Niggli, K. Kitajima, L. Rattan, and C. Sadoff. 2021. Boost nature positive production: a paper on action track 3. A paper from the Scientific Group of the UN Food Systems Summit. https://sc-fss2021.org/wp-content/uploads/2021/04/ Action_Track_3_paper_Boost_Nature_Positive_Production.pdf. Accessed 5 Sept 2021.

Holt-Giménez, E., and M.A. Altieri. 2013. Agroecology, food sovereignty and the new green revolution. Journal of Sustainable Agriculture 37 (1): 90-102. https://doi.org/10.1080/10440046. 2012.716388.

Holt Giménez, E., and A. Shattuck. 2011. Food crises, food regimes and food movements: Rumblings of reform or tides of transformation? Journal of Peasant Studies 38 (1): 109-144. https://doi org/10.1080/03066150.2010.538578.

IGI (Innovative Genomics Institute). 2021. Genome editing of the staple crop cassava to eliminate toxic cyanogen production. Innovative Genomics Institute (IGI). https://innovativegenom ics.org/projects/genome-editing-staple-crop-cassava-eliminatetoxic-cyanogen-production/. Accessed 5 Sept 2021.

Iles, A. 2021. Can Australia transition to an agroecological future? Agroecology and Sustainable Food Systems 45 (1): 3-41. https:// doi.org/10.1080/21683565.2020.1780537.

Illich, I. 1973. Tools for conviviality. New York: Harper \& Row.

Innovature. 2019. Gene editing a sweet solution for weakened cacao trees. May 2. https://innovature.com/article/gene-editing-sweetsolution-weakened-cacao-trees. Accessed 5 Sept 2021.

IPES-Food (International Panel of Experts on Sustainable Food Systems). 2016. From uniformity to diversity: A paradigm shift from industrial agriculture to diversified agroecological systems. http://www.ipes-food.org/_img/upload/files/UniformityToDiv ersity_FULL.pdf. Accessed 5 Sept 2021.

IPES-Food (International Panel of Experts on Sustainable Food Systems). 2017. Too big to feed: Exploring the impacts of megamergers, consolidation, and concentration of power in the agrifood sector. http://www.ipes-food.org/images/Reports/Concentrat ion_FullReport.pdf. Accessed 5 Sept 2021.

ISAAA (International Service for the Acquisition of Agri-biotech Applications). 2019. ISAAA brief 55-2019: biotech crops drive socio-economic development and sustainable environment in the 
new frontier. https://www.isaaa.org/resources/publications/briefs/ 55/executivesummary/default.asp. Accessed 4 Sept 2021.

Jasanoff, S., ed. 2004. States of knowledge: The co-production of science and social order. International Library of Sociology. London: Routledge.

Johnson, N. 2015. It's practically impossible to define "GMOs." Vox. December 26. https://www.vox.com/2015/12/26/10653372/ gmos-definition. Accessed 5 September 2021.

Jonas, T. 2021. Peoples' solutions to food systems transformation in Asia and the Pacific. Development. https://doi.org/10.1057/ s41301-021-00306-z.

Khumsupan, P., S. Donovan, and A.J. McCormick. 2019. CRISPR/Cas in Arabidopsis: Overcoming challenges to accelerate improvements in crop photosynthetic efficiencies. Physiologia Plantarum 166 (1): 428-437. https://doi.org/10.1111/ppl.12937.

Kloppenburg, J.R. 2004. First the seed: the political economy of plant biotechnology, 1492-2000. 2nd ed. Science and Technology in Society. Madison, WI: University of Wisconsin Press.

Kremen, C. 2015. Reframing the land-sparing/land-sharing debate for biodiversity conservation: Reframing the land-sparing/landsharing debate. Annals of the New York Academy of Sciences 1355 (1): 52-76. https://doi.org/10.1111/nyas.12845.

Kremen, C., and A.M. Merenlender. 2018. Landscapes that work for biodiversity and people. Science 362 (6412): eaau6020. https:// doi.org/10.1126/science.aau6020.

Kremen, C., and A. Miles. 2012. Ecosystem services in biologically diversified versus conventional farming Systems: Benefits, externalities, and trade-Offs. Ecology and Society. https://doi.org/10. 5751/ES-05035-170440.

Kuzma, J., and K. Grieger. 2020. Community-led governance for geneedited crops. Science 370: 916-918. https://doi.org/10.1126/scien ce.abd1512.

LaManna, C.M., and R. Barrangou. 2018. Enabling the rise of a CRISPR world. The CRISPR Journal 1 (3): 205-208. https:// doi.org/10.1089/crispr.2018.0022.

Lemmon, Z.H., N.T. Reem, J. Dalrymple, S. Soyk, K.E. Swartwood, D. Rodriguez-Leal, J. Van Eck, and Z.B. Lippman. 2018. Rapid improvement of domestication traits in an orphan crop by genome editing. Nature Plants 4 (10): 766-770. https://doi.org/ 10.1038/s41477-018-0259-X.

Levidow, L., M. Pimbert, and G. Vanloqueren. 2014. Agroecological research: Conforming-Or transforming the dominant agro-food regime? Agroecology and Sustainable Food Systems 38 (10): 1127-1155. https://doi.org/10.1080/21683565.2014.951459.

Liboiron, M. 2021. Pollution is colonialism. Durham, NC: Duke University Press.

Liu, G., J. Li, and I.D. Godwin. 2019. Genome editing by CRISPR/ Cas9 in sorghum through biolistic bombardment. In Sorghum, ed. Zuo-Yu Zhao and Jeff Dahlberg. 1931, 169-183. Methods in molecular biology. New York: Springer. https://doi.org/10.1007/ 978-1-4939-9039-9_12

Lotz, L.A., C.C. van de Wiel, and M.J. Smulders. 2020. Genetic engineering at the heart of agroecology. Outlook on Agriculture 49 (1): 21-28. https://doi.org/10.1177/0030727020907619.

Lucheta, A.R., and M. Rodrigues Lambais. 2012. Sulfur in agriculture. Revista Brasileira De Ciência Do Solo 36 (5): 1369-1379. https://doi.org/10.1590/S0100-06832012000500001.

Mackelprang, R. 2018. Organic farming with gene editing: An oxymoron or a tool for sustainable agriculture? The Conversation, October 10. https://theconversation.com/organic-farming-withgene-editing-an-oxymoron-or-a-tool-for-sustainable-agriculture101585. Accessed 5 Sept 2021.

Macnaghten, P., and M.G. Habets. 2020. Breaking the impasse: Towards a forward-looking governance framework for gene editing with plants. Plants, People, Planet 2 (4): 353-365. https://doi.org/10.1002/ppp3.10107.

Marya, R., and R. Patel. 2021. Inflamed: Deep medicine and the anatomy of injustice. New York: Farrar, Straus and Giroux.

McKittrick, K. 2021. Dear science and other stories. Errantries. Durham, NC: Duke University Press.

Méndez, E.V., C.M. Bacon, and R. Cohen. 2013. Agroecology as a transdisciplinary, participatory, and action-oriented approach. Agroecology and Sustainable Food Systems 37 (1): 3-18. https:// doi.org/10.1080/10440046.2012.736926.

Mignolo, W.D., and A. Escobar, eds. 2013. Globalization and the decolonial option. London: Routledge.

Miladinovic, D., D. Antunes, K. Yildirim, A. Bakhsh, S. Cvejić, A. Kondić-Špika, A.M. Jeromela, H. Opsahl-Sorteberg, A. Zambounis, and Z. Hilioti. 2021. Targeted plant improvement through genome editing: From laboratory to field. Plant Cell Reports 40 (6): 935-951. https://doi.org/10.1007/s00299-020-02655-4.

Montenegro de Wit, M. 2020. Democratizing CRISPR? Stories, practices, and politics of science and governance on the agricultural gene editing frontier. Elementa Science of the Anthropocene 8 (1): 9. https://doi.org/10.1525/elementa.405.

Montenegro de Wit, M. and A. Iles. 2021. Woke science and the 4th Industrial Revolution: inside the making of UNFSS knowledge. Development. October 19. https://doi.org/10.1057/ s41301-021-00314-z

Morales, H. 2021. Agroecological feminism. Agroecology and Sustainable Food Systems 45 (7): 955-956. https://doi.org/10.1080/ 21683565.2021 .1927544$.

Murdock, A. 2020. Using CRISPR genome editing to make cyanidefree cassava. Innovative Genomics Institute (IGI), July 14. https://innovativegenomics.org/news/crispr-cyanide-free-cassa $\mathrm{va} /$. Accessed 5 Sept 2021.

Nelson, A. 2016. The social life of DNA: Race, reparations, and reconciliation after the genome. Boston: Beacon Press.

Nyantakyi-Frimpong, H., J. Kangmennaang, R. Bezner Kerr, I. Luginaah, L. Dakishoni, E. Lupafya, L. Shumba, and M. Katundu. 2017. Agroecology and healthy food systems in semi-humid tropical Africa: Participatory research with vulnerable farming households in Malawi. Acta Tropica 175 (November): 42-49. https://doi.org/10.1016/j.actatropica.2016.10.022.

Nyéléni. 2015. Declaration of the International Forum for Agroecology, Nyéléni, Mali. Development 58 (2-3): 163-168. https://doi. org/10.1057/s41301-016-0014-4.

Nyéléni Newsletter. 2019. Nyéléni Newsletter, no. 36. https://nyeleni. org/DOWNLOADS/newsletters/Nyeleni_Newsletter_Num_36_ EN.pdf. Accessed 5 Sept 2021.

Odum, E.P. 1969. The strategy of ecosystem development. Science 164 (3877): 262-270.

Oliva, R., C. Ji, G. Atienza-Grande, J.C. Huguet-Tapia, A. PerezQuintero, T. Li, J.S. Eom, et al. 2019. Broad-spectrum resistance to bacterial blight in rice using genome editing. Nature Biotechnology 37 (11): 1344-1350. https://doi.org/10.1038/ s41587-019-0267-z.

Otherwise School. 2021. Tools and techniques of counter-fascism, June 14-July 23, 2021 I a summer curriculum. https://sites.uw.edu/ otherwise/. Accessed 7 June 2021.

Patel, R. 2009. Food sovereignty. The Journal of Peasant Studies 36 (3): 663-706. https://doi.org/10.1080/03066150903143079.

Patel, R. 2013. The long green revolution. The Journal of Peasant Studies 40 (1): 1-63. https://doi.org/10.1080/03066150.2012.719224.

Pechlaner, G., and G. Otero. 2008. The third food regime: Neoliberal globalism and agricultural biotechnology in North America. Sociologia Ruralis 48 (4): 351-371. https://doi.org/10.1111/j. 1467-9523.2008.00469.x. 
Perfecto, I., and J. Vandermeer. 2010. The agroecological matrix as alternative to the land-sparing/agriculture intensification model. Proceedings of the National Academy of Sciences 107 (13): 5786-5791. https://doi.org/10.1073/pnas.0905455107.

Perkins, J.H. 1990. The Rockefeller Foundation and the green revolution, 1941-1956. Agriculture and Human Values 7 (3-4): 6-18. https://doi.org/10.1007/BF01557305.

Phelps, M. 2019. Gene editing delivers major sorghum protein lift. Queensland Country Life. November 19. http://www.queensland countrylife.com.au/story/6500841/gene-editing-delivers-majorsorghum-protein-lift/. Accessed 5 Sept 2021.

Phillips MacDougall. 2011. The cost and time involved in the discovery, development and authorisation of a new plant biotechnology derived trait. United Kingdom. https://croplife.org/wp-content/ uploads/2014/04/Getting-a-Biotech-Crop-to-Market-PhillipsMcDougall-Study.pdf. Accessed 5 Sept 2021.

Pimbert, M.P., and B. Barry. 2021. Let the people decide: Citizen deliberation on the role of GMOs in Mali's agriculture. Agriculture and Human Values. https://doi.org/10.1007/s10460-021-10221-1.

Pimbert, M. P., N. I. Moeller, J. Singh, and C. R. Anderson. 2021. Agroecology. Oxford Research Encyclopedia of Anthropology. August 31. https://doi.org/10.1093/acrefore/9780190854584. 013.298.

Prahladachar, M. 1983. Income distribution effects of the green revolution in India: A review of empirical evidence. World Development 11 (11): 927-944. https://doi.org/10.1016/0305-750X(83) 90055-4.

Quijano, A. 2007. Coloniality and modernity/rationality. Cultural Studies 21 (2-3): 168-178. https://doi.org/10.1080/0950238060 1164353.

Raffan, S., J. Oddy, and N.G. Halford. 2020. The sulphur response in wheat grain and its implications for acrylamide formation and food safety. International Journal of Molecular Sciences 21 (11): 3876. https://doi.org/10.3390/ijms21113876.

Raffan, S., C. Sparks, A. Huttly, L. Hyde, D. Martignago, A. Mead, S.J. Hanley, et al. 2021. Wheat with greatly reduced accumulation of free asparagine in the grain, produced by CRISPR/Cas9 editing of asparagine synthetase gene TaASN2. Plant Biotechnology Journal. https://doi.org/10.1111/pbi.13573.

Ravetz, J.R. 2006. No-nonsense guide to science. The No-Nonsense Guides. Oxford: New Internationalist.

Regalado, A. 2015. Everything You Need to Know About CRISPR Gene Editing's Monster Year. MIT Technology Review, December 1. https://www.technologyreview.com/s/543941/everythingyou-need-to-know-about-crispr-gene-editings-monster-year/. Accessed 6 Sept 2021.

Robinson, C. 2019. Why regulation of gene editing will not hurt small and medium size companies. GM Watch. November 28. https:// www.gmwatch.org/en/news/archive/2019/19239-why-regulationof-gene-editing-will-not-hurt-small-and-medium-size-compa nies. Accessed 2 Sept 2021.

Rock, J. 2019. "We are not starving:" Challenging genetically modified seeds and development in Ghana. Culture, Agriculture, Food and Environment 41 (1): 15-23. https://doi.org/10.1111/cuag.12147.

Rodney, W. 1972 [2018]. How Europe underdeveloped Africa. New York: Verso.

Ronald, P. 2015. TED Talks: The case for engineering our food. https:// www.ted.com/talks/pamela_ronald_the_case_for_engineering our_food. Accessed 2 Sept 2021.

Ronald, P., and R.W. Adamchak. 2008. Tomorrow's table: Organic farming, genetics, and the future of food. New York: Oxford University Press.

Rosset, P., and M.A. Altieri. 2017. Agroecology: science and politics. Agrarian Change \& Peasant Studies. United Kingdom: Practical Action Publishing.
Rothamsted. 2021. GE field trial application submitted to Defra. Rothamsted Research. May 6. https://www.rothamsted.ac.uk/ news/ge-field-trial-application-submitted-defra. Accessed 7 June 2021.

Rotz, S., E. Duncan, M. Small, J. Botschner, R. Dara, I. Mosby, M. Reed, and E.D.G. Fraser. 2019. The politics of digital agricultural technologies: A preliminary review. Sociologia Ruralis 59 (2): 203-229. https://doi.org/10.1111/soru.12233.

Saini, A. 2019. Superior: The return of race science. Boston: Beacon Press.

Schultink, A., T. Qi, A. Lee, A.D. Steinbrenner, and B. Staskawicz. 2017. Roq1 mediates recognition of the Xanthomonas and Pseudomonas effector proteins XopQ and HopQ1. The Plant Journal 92 (5): 787-795. https://doi.org/10.1111/tpj.13715.

Shapin, S. 1994. A social history of truth: Civility and science in seventeenth-century England. Chicago: University of Chicago Press.

Sharma, H.R. 1994. Distribution of landholdings in rural India, 195354 to 1981-82: Implications for land reforms. Economic and Political Weekly 29 (13): A12-A25.

Sherkow, J. 2015. The CRISPR patent interference showdown is on: how did we get here and what comes next? Stanford Law School. December 29. https://law.stanford.edu/2015/12/29/the-crisprpatent-interference-showdown-is-on-how-did-we-get-here-andwhat-comes-next/. Accessed 5 Sept 2021.

Shotwell, A. 2016. Against purity: Living ethically in compromised times. Minneapolis, MN: University of Minnesota Press.

Sievers-Glotzbach, S., and A. Christinck. 2021. Introduction to the symposium: Seed as a commons-exploring innovative concepts and practices of governing seed and varieties. Agriculture and Human Values 38 (2): 499-507. https://doi.org/10.1007/ s10460-020-10166-x.

Stein, S. 2019. Beyond higher education as we know it: Gesturing towards decolonial horizons of possibility. Studies in Philosophy and Education 38 (2): 143-161. https://doi.org/10.1007/ s11217-018-9622-7.

Stein, S., D. Hunt, R. Suša, and V. de Oliveira Andreotti. 2017. The educational challenge of unraveling the fantasies of ontological security. Diaspora, Indigenous, and Minority Education 11 (2): 69-79. https://doi.org/10.1080/15595692.2017.1291501.

Stone, G.D. 2017. Dreading CRISPR: GMOs, honest brokers, and Mertonian transgressions. Geographical Review. https://doi.org/10. 1111 /gere. 12260 .

Stone, G.D., and D. Glover. 2017. Disembedding grain: Golden rice, the green revolution, and heirloom seeds in the Philippines. Agriculture and Human Values 34 (1): 87-102. https://doi.org/10. 1007/s10460-016-9696-1.

Suárez-Torres, J., J. Ricardo Suárez-López, D. López-Paredes, H. Morocho, L. Enrique Cachiguango-Cachiguango, and W. Dellai. 2017. Agroecology and health: Lessons from indigenous populations. Current Environmental Health Reports 4 (2): 244-251. https://doi.org/10.1007/s40572-017-0146-z.

Subramian, K. 2015. Revisiting the green revolution: irrigation and food production in twentieth-century India. United Kingdom: King's College, London. https://kclpure.kcl.ac.uk/portal/en/ theses/revisiting-the-green-revolution(c7fedff0-862a-4fdb-aef80526f78772b5).html. Accessed 6 Sept 2021.

TallBear, K. 2013. Native American DNA: Tribal belonging and the false promise of genetic science. Minneapolis, MN: University of Minnesota Press.

Tavella, E. 2016. How to make participatory technology assessment in agriculture more "participatory": The case of genetically modified plants. Technological Forecasting and Social Change 103 (February): 119-126. https://doi.org/10.1016/j.techfore.2015. 10.015 . 
Taylor, A.P. 2019. Companies use CRISPR to improve crops. The Scientist Magazine. February 1. https://www.the-scientist.com/ bio-business/companies-use-crispr-to-improve-crops-65362. Accessed 6 Sept 2021.

TestBiotech. 2019. Patent cartel for the large companies. TestBiotech. June 24. https://www.testbiotech.org/en/printpdf/2378. Accessed 5 Sept 2021.

The Red Nation. 2021. The Red Deal: Indigenous action to save our earth. Brooklyn, NY: Common Notions.

The Royal Society. 2009. Reaping the benefits: Science and the sustainable intensification of global agriculture. London, UK: The Royal Society.

Tischler, W. 1965. Agrarökologie. Jena: Fischer.

Tittonell, P. 2014. Ecological intensification of agriculture-sustainable by nature. Current Opinion in Environmental Sustainability 8 (October): 53-61. https://doi.org/10.1016/j.cosust.2014.08.006.

Tomlinson, I. 2013. Doubling food production to feed the 9 billion: A critical perspective on a key discourse of food security in the UK. Journal of Rural Studies 29 (January): 81-90. https://doi.org/10. 1016/j.jrurstud.2011.09.001.

Tsing, A.L., J. Deger, A. Keleman Saxena, and F. Zhou. 2020. Feral atlas: The more-than-human Anthropocene. Redwood City, CA: Stanford University Press.

Tuhiwai Smith, L. 2012. Decolonizing methodologies: Research and indigenous peoples, 2nd ed. London: Zed Books.

UNFSS (UN Food Systems Summit). 2021. Session 4: Why the fight: getting to grips with missed opportunities and contentious issues in science and innovation for food systems July 8, Science Days. https://sc-fss2021.org/events/sciencedays/program/. Accessed 31 Oct 2021.

USFSA (US Food Sovereignty Alliance). n.d. "Food Sovereignty"। USFSA. http://usfoodsovereigntyalliance.org/what-is-food-sover eignty/. Accessed 7 June 2021.

Vandermeer, J., and I. Perfecto. 2013. Complex traditions: Intersecting theoretical frameworks in agroecological research. Journal of Agroecology and Sustainable Food Systems 37 (1): 76-89. https://doi.org/10.1080/10440046.2012.717904.

Vanloqueren, G., and P.V. Baret. 2009. How agricultural research systems shape a technological regime that develops genetic engineering but locks out agroecological innovations. Research Policy 38 (6): 971-983. https://doi.org/10.1016/j.respol.2009. 02.008 .

Vivero Pol, J.L., T. Ferrando, O. de Schutter, and U. Mattei, eds. 2019. Routledge handbook of food as a commons. Abingdon: Routledge.

von Braun, J., K. Afsana, L.O. Fresco, and M. Hassan. 2021. Food systems: Seven priorities to end hunger and protect the planet. Nature 597 (7874): 28-30. https://doi.org/10.1038/ d41586-021-02331-x.

Wang, X., J. Li, F. Li, Y. Pan, D. Cai, D. Mao, L. Chen, and S. Luan. 2021. Rice potassium transporter OsHAK8 mediates K+ uptake and translocation in response to low $\mathrm{K}+$ stress. Frontiers in Plant Science 12 (August): 730002. https://doi.org/10.3389/fpls.2021. 730002.

Warner, K.D., K.M. Daane, C.M. Getz, S.P. Maurano, S. Calderon, and K.A. Powers. 2011. The decline of public interest agricultural science and the dubious future of crop biological control in California. Agriculture and Human Values 28 (4): 483-496. https://doi.org/10.1007/s10460-010-9288-4.

Wattnem, T. 2016. Seed laws, certification and standardization: Outlawing informal seed systems in the Global South. The Journal of Peasant Studies 43 (4): 850-867. https://doi.org/10.1080/03066 150.2015.1130702.
WEF (World Economic Forum). 2018. Innovation with a purpose: the role of technology innovation in accelerating food systems transformation. http://www3.weforum.org/docs/WEF_Innov ation_with_a_Purpose_VF-reduced.pdf. Accessed 5 Sept 2021.

WEF (World Economic Forum). 2020. Nature risk rising: why the crisis engulfing nature matters for business and the economy. New Nature Economy Series. Geneve, Switzerland: World Economic Forum. http://www3.weforum.org/docs/WEF_New_Nature_ Economy_Report_2020.pdf. Accessed 5 Sept 2021.

Werner, M., A. Shattuck, and R. Galt. 2021. While debate rages over glyphosate-based herbicides, farmers are spraying them all over the world. The Conversation. July 3. http://theconversation.com/ while-debate-rages-over-glyphosate-based-herbicides-farmersare-spraying-them-all-over-the-world-161156. Accessed 5 Sept 2021.

Willett, W., J. Rockström, B. Loken, M. Springmann, T. Lang, S. Vermeulen, T. Garnett, et al. 2019. Food in the Anthropocene: The EAT-Lancet Commission on healthy diets from sustainable food systems. The Lancet 393 (10170): 447-492. https://doi.org/10. 1016/S0140-6736(18)31788-4.

Wright, A.L. 2005. The death of Ramón González: The modern agricultural dilemma. Rev. Austin: University of Texas Press.

Yapa, L. 1993. What are improved seeds? An epistemology of the green revolution. Economic Geography 69 (3): 254-273. https://doi. org/10.2307/143450.

Yazzie, M. 2021. To Palestine, with love. Red Power Hour. Co-hosts Elena Ortiz and Justine Teba. https://directory.libsyn.com/episo de/index/show/therednation/id/19210127. Accessed 14 June 2021.

Zaitchik, A. 2021. The great American science heist. The Intercept. https://theintercept.com/2021/08/29/bayh-dole-act-public-scien ce-patents/. Accessed 5 Sept 2021.

Zsögön, A., T. Čermák, E. Rezende Naves, M.M. Notini, K.H. Edel, S. Weinl, L. Freschi, D.F. Voytas, J. Kudla, and L.E. Pereira Peres. 2018. De novo domestication of wild tomato using genome editing. Nature Biotechnology 36 (12): 1211-1216. https://doi.org/ $10.1038 /$ nbt. 4272 .

Zuluaga Sánchez, G.P., G. Catacora-Vargas, and E. Siliprandi. 2018. Agroecología en femenino: reflexiones a partir de nuestras experiencias. La Paz, Bolivia: SOCLA / CLACSO.

Publisher's Note Springer Nature remains neutral with regard to jurisdictional claims in published maps and institutional affiliations.

Maywa Montenegro de Wit works as an Assistant Professor in the department of Environmental Studies at the University of California, Santa Cruz. She draws on political ecology, science and technology studies, and agrarian political economy to look broadly at knowledge politics in struggles over food systems. Her research interests include complex pathways connecting agrobiodiversity to food sovereignty, food security, and nutrition; epistemic and material struggles over agroecology at the international level; CRISPR and other new technologies' influence on food system trajectories; and scholar-activism as a decolonial praxis to advance agroecology and food sovereignty. She is a co-founder of the Agroecology Research-Action collective and serves as an Associate Editor for the journal of Agroecology and Sustainable Food Systems. 